\title{
Hurricane Sandy Effects on Coastal Marsh Elevation Change
}

Alice G. Yeates

James B. Grace

et al

Scott Lerberg

Virginia Institute of Marine Science

James C. Lynch

See next page for additional authors

Follow this and additional works at: https://scholarworks.wm.edu/vimsarticles

Part of the Geomorphology Commons

\section{Recommended Citation}

Yeates, Alice G.; Grace, James B.; et al; Lerberg, Scott; Lynch, James C.; Maher, Nichole; Megonigal, J.Patrick; Reay, W. G.; and et al, Hurricane Sandy Effects on Coastal Marsh Elevation Change (2020). Estuaries and Coasts, 43, 1640-1657. doi: $10.1007 / \mathrm{s} 12237-020-00758-5$

This Article is brought to you for free and open access by the Virginia Institute of Marine Science at W\&M ScholarWorks. It has been accepted for inclusion in VIMS Articles by an authorized administrator of W\&M ScholarWorks. For more information, please contact scholarworks@wm.edu. 


\section{Authors}

Alice G. Yeates, James B. Grace, et al, Scott Lerberg, James C. Lynch, Nichole Maher, J.Patrick Megonigal, W. G. Reay, and et al 


\title{
Hurricane Sandy Effects on Coastal Marsh Elevation Change
}

\author{
Alice G. Yeates ${ }^{1}$ - James B. Grace ${ }^{2}$ • Jennifer H. Olker ${ }^{1}$ - Glenn R. Guntenspergen ${ }^{3}$ - Donald R. Cahoon ${ }^{3}$ (D) \\ Susan Adamowicz ${ }^{4}$. Shimon C. Anisfeld ${ }^{5}$. Nels Barrett ${ }^{6}$ - Alice Benzecry ${ }^{7} \cdot$ Linda Blum $^{8} \cdot$ Robert R. Christian ${ }^{9}$. \\ Joseph Grzyb ${ }^{10}$. Ellen Kracauer Hartig ${ }^{11,12}$. Kelly Hines Leo ${ }^{13}$. Scott Lerberg ${ }^{14}$. James C. Lynch $^{15} \cdot$ Nicole Maher $^{16}$. \\ J. Patrick Megonigal ${ }^{17} \cdot$ William Reay $^{14} \cdot$ Drexel Siok $^{18} \cdot$ Adam Starke $^{13} \cdot$ Vincent Turner $^{19} \cdot$ Scott Warren $^{20}$
}

Received: 27 March 2019 / Revised: 20 March 2020 / Accepted: 11 May 2020 / Published online: 19 June 2020

(C) This is a U.S. government work and not under copyright protection in the U.S.; foreign copyright protection may apply 2020

\begin{abstract}
High-magnitude storm events such as Hurricane Sandy are powerful agents of geomorphic change in coastal marshes, potentially altering their surface elevation trajectories. But how do a storm's impacts vary across a large region spanning a variety of wetland settings and storm exposures and intensities. We determined the short-term impacts of Hurricane Sandy at 223 surface elevation table-marker horizon stations in estuarine marshes located across the northeast region of the United States by comparing poststorm surface elevation change with pre-storm elevation trends. We hypothesized that the storm's effect on marsh elevation trends would be influenced by position relative to landfall (right or left) and distance from landfall. The structural equation model presented predicts that marshes located to the left of landfall were more likely to experience an elevation gain greater than expected, and this positive deviation from pre-storm elevation trends tended to have a greater magnitude than those experiencing negative deviations (elevation loss), potentially due to greater sediment deposition. The magnitude of negative deviations from elevation change in marshes to the right of landfall was greater than for positive deviations, with a greater effect in marshes within $200 \mathrm{~km}$ of landfall, potentially from the extent and magnitude of storm surge. Overall, results provide an integrated picture of how storm characteristics combined with the local wetland setting are important to a storm's impact on surface elevation, and that the surface elevation response can vary widely among sites across a region impacted by the same storm.
\end{abstract}

Keywords Hurricane Sandy $\cdot$ Marsh dynamics $\cdot$ Storm impacts $\cdot$ Surface elevation table $\cdot$ marker horizon $\cdot$ SET-MH $\cdot$ Structural equation modeling

\section{Introduction}

Understanding the impacts of tropical cyclones on the stability and resilience of coastal wetlands is important considering the change in the observed and projected frequencies and relative intensities of storm events, and the need for coastal wetlands to trap and retain adequate sediment loads to keep pace with rising sea levels (Knutson et al. 2010; Bender et al. 2010; Peduzzi et al. 2012; Emanuel 2013; Hall and Sobel 2013;

Communicated by: Charles Simenstad

Electronic supplementary material The online version of this article (https://doi.org/10.1007/s12237-020-00758-5) contains supplementary material, which is available to authorized users.

Donald R. Cahoon

dcahoon@usgs.gov

Extended author information available on the last page of the article
Horton et al. 2011, 2014; Leonardi et al. 2018). Previous research has shown that low-frequency, high-magnitude storm events are powerful agents of geomorphic change, resulting in both positive and negative changes in elevation trajectories through impacts on both the surface and subsurface soil processes controlling marsh surface elevation (Cahoon 2006; Day et al. 2008). These processes can include sediment deposition and erosion, storm surge-related soil compaction, and altered plant community dynamics, the latter of which may include mortality of existing vegetation or promotion of growth through increased availability of nutrients from newly deposited sediment (Cahoon et al. 1995; Cahoon 2006; Day et al. 2008; Castagno et al. 2018). Death of wetland vegetation can lead to loss of elevation by increased root zone decomposition and erosion, whereas increased root growth can lead to elevation gain by root zone expansion (Cahoon et al. 2003; Day et al. 2011). Marsh erosion can affect the ability of estuarine systems to retain sediment inputs and can also lead to a loss of sediment trapping potential of marsh platforms 
resulting in further deterioration of salt marshes through a positive feedback-loop (e.g., Donatelli et al. 2018).

The physical characteristics of a storm (e.g., wind speed, storm surge height, impact angle of landfall) combined with local wetland conditions (e.g., marsh primary productivity and health, groundwater level, elevation capital, tidal range) are important factors determining a storm's impact on marsh surface elevation (Mallin and Corbett 2006; Inamdar et al. 2011; Fagherazzi 2014). Some fundamental physical characteristics of tropical cyclones in the northern hemisphere include elevated wind speeds that push and pile-up seawater as the storm advances over the ocean and counter-clockwise winds. The latter characteristic means that a storm's physical impacts are typically greater in the northeast quadrant (i.e., the upper right quadrant relative to storm direction) where winds blow toward shore as the storm approaches the coast. Yet, every storm is unique in terms of its wind speed, size (storm diameter), rate of forward motion, amount of rainfall, timing of landfall relative to tide height, angle of approach to the shore, and the local nearshore bathymetry and coastal geomorphology at the point of landfall (Prandle and Wolf 1978; Resio and Westerink 2008; Aretxabaleta et al. 2014, Aretxabaleta et al. 2016). This unique set of physical characteristics determines the intensity and duration of a storm's impact on coastal landforms it encounters.

On October 28, 2012, Hurricane Sandy traveled north on a track parallel to the Atlantic coast of the United States, with the strongest winds on its western side (Fig. 1; and see Fig. 7 in Blake et al. 2013). When the hurricane reached the midAtlantic region (National Aeronautics and Space Administration 2013; Fig. 1b, c), it combined with a cold front moving from the northwest. The storm turned to the northwest and made landfall on October 29, 2012, as a large $1611 \mathrm{~km}$ diameter post-tropical cyclone near Brigantine, NJ (Fig. 1a), with maximum sustained winds of $130 \mathrm{~km} / \mathrm{h}$ (Blake et al. 2013). As a result of this turn, coastal habitats located to the right (north) of the landfall point continued to be besieged by winds of the Hurricane's northeast quadrant pushing water ashore. Conversely, coastal habitats located to the left (south) of the landfall point experienced strong winds out of the northwest shifting to out of the southwest during storm passage (Fig. 1b, c), thereby limiting the extent and depth of storm surge in this region (Dennison et al. 2012).

The major impacts of Hurricane Sandy on coastal environments were related to the effects of storm surge and associated coastal flooding (Blake et al. 2013; Valle-Levinson et al. 2013). Several factors contributed to the creation of record high storm surge and coastal inundations in the New Jersey, New York, and Connecticut region north of landfall. In addition to the large storm extent, Hurricane Sandy made landfall at high tide and at an angle closer to perpendicular to the New Jersey shore than any hurricane in the historical record (Hall and Sobel 2013). The return period for a storm of Hurricane
Sandy's intensity with this angle of approach is 714 years (Hall and Sobel 2013). These factors, combined with the configuration of the New Jersey-New York-Connecticut shoreline and New York Bight bathymetry, caused the storm surge to rise up to $3.86 \mathrm{~m}$ in the vicinity of New York City (Blake et al. 2013). A record storm tide (the combination of the storm surge and astronomical tide) of $4.28 \mathrm{~m}$ was recorded at the Battery in New York City (Blake et al. 2013). Historical increases in sea level and mean flood heights contributed to the record high storm surge and storm tide heights at New York City generated by Hurricane Sandy (Kemp and Horton 2013; Talke et al. 2014; Kemp et al. 2017; Reed et al. 2015). Consequently, the flooding depths over upland ground level in parts of this region of the coast were as much as $3 \mathrm{~m}$ (Blake et al. 2013) during Hurricane Sandy. In contrast, the peak in storm surge height to the left of landfall in the coastal bays of the Delmarva Peninsula behind Fenwick and Assateague barrier islands was only $\sim 1.2 \mathrm{~m}$ (Dennison et al. 2012).

Surface elevation change in a wetland following a storm can vary widely among multiple sites impacted by the same storm and among different storms for the same site given the unique characteristics of different wetland types and storm events (Cahoon 2006). Thus, changes in surface elevation trends should not simply be extrapolated from one wetland to another for any given storm, or from one storm to another for any given wetland. However, by using surface elevation data collected across a large geographic area that spans a variety of wetland settings, as well as storm exposures and intensities, we can improve our understanding of wetland vulnerability and provide predictive capability of severe storm impacts on marsh surface elevation change.

The goal of this study was to evaluate Hurricane Sandy's short-term impacts on marsh surface elevations by analyzing elevation data collected from marshes of the northeastern region of the United States, both before and after the storm, using the surface elevation tablemarker horizon (SET-MH) method (Cahoon et al. 1995; Webb et al. 2013). We hypothesized that differences in storm surge extent and duration on either side of a storm's point of landfall and within different geomorphic settings could differentially influence the coastal marsh processes related to sediment deposition, sediment erosion, and soil compaction ultimately resulting in changes in marsh elevation trends. In addition to the variation in marsh exposure to storm processes, we hypothesized that pre-storm surface elevation trends (rate of change and degree of variation) may influence post-storm deviations from expected change. We predicted that processes driving large variations in pre-storm elevation changes would continue to do so and these marshes would experience greater poststorm deviation from expected. We had no particular expectation for or against there being an effect of rate of 

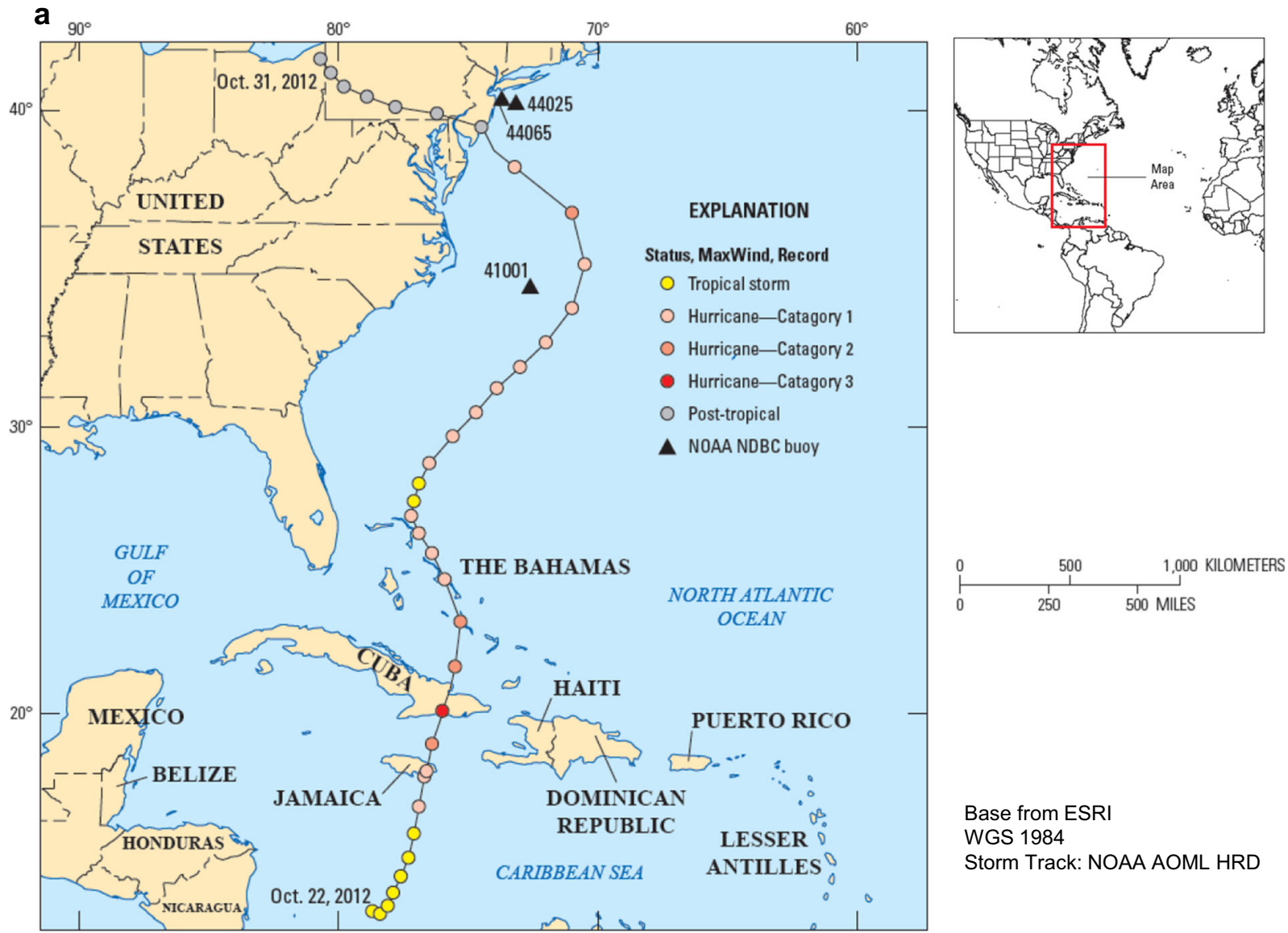

Base from ESRI

WGS 1984

Storm Track: NOAA AOML HRD

b

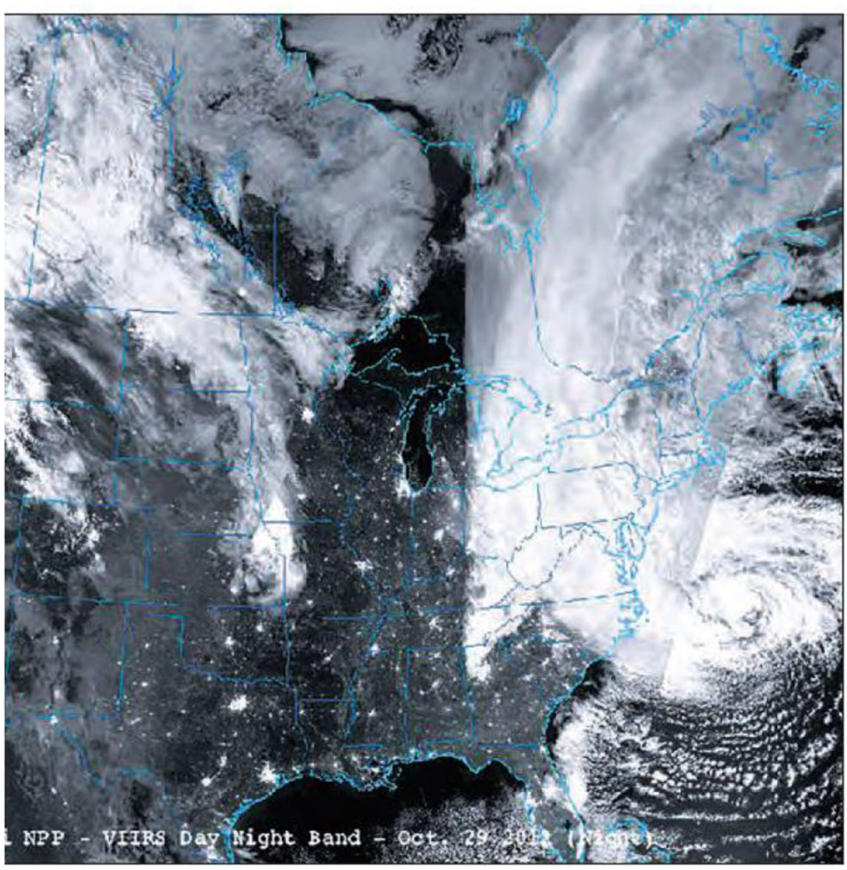

Fig. 1 a Map showing Hurricane Sandy track and intensity, as well as locations of moored National Oceanic and Atmospheric Administration (National Oceanic and Atmospheric Administration 2010) National Data Buoy Center (NDBC) buoys recording wave height and period (adapted from Sopkin et al. 2014). b Nighttime image of Hurricane Sandy captured $16-18 \mathrm{~h}$ before landfall by the Visible Infrared Imaging Radiometer Suite
C

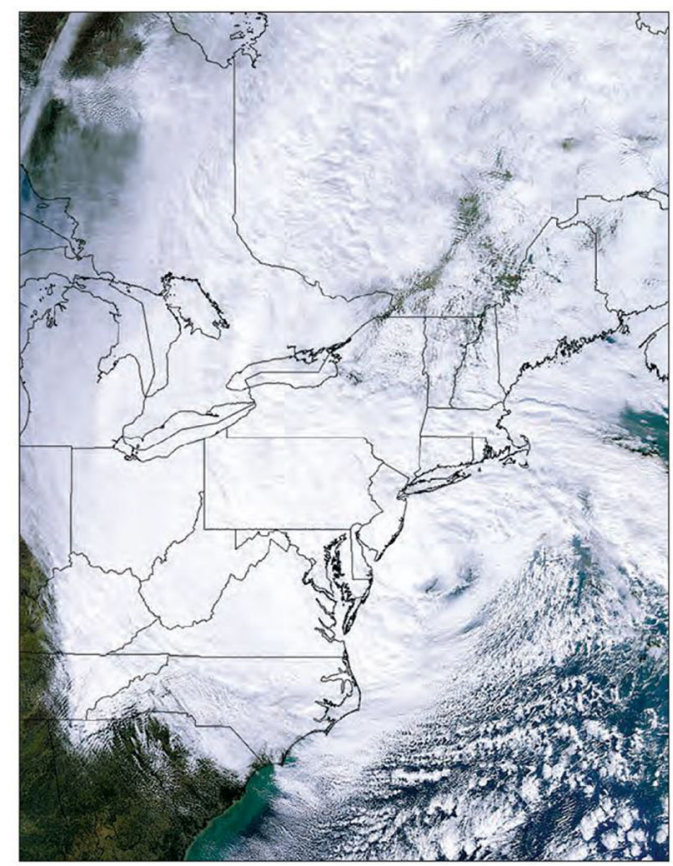

(VIIRS) on the National Aeronautics and Space Administration (NASA)/ NOAA Suomi National Polar-orbiting Partnership satellite, a composite of several satellite passes (image provided by University of WisconsinMadison). c NASA Aqua satellite image of Hurricane Sandy, October 29, 2012, 2:20 p.m. EDT (NASA 2013; both images accessed at www.nasa. gov/mission_pages/hurricanes/archives/2012/h2012_Sandy.html\#11) 
change prior to the storm and included this variable in our initial model to minimize a possible source of error. These assessments of coastal wetland responses were then used to estimate the impact of Hurricane Sandy on marsh sustainability and the potential impact of similar future storms.

\section{Methods}

\section{Study Area and SET-MH Stations}

The study area included estuarine and back-barrier lagoonal tidal wetlands along the northeastern coast of the United States from Virginia to Maine, an area that spans the track of the storm as it turned north toward the US coast (Fig. 1). Plant communities were predominantly dominated, or co-dominated, by Spartina alterniflora, Spartina patens, Schoenoplectus americanus, or Distichlis spicata, with less than 5\% dominated, or co-dominated, by Salicornia spp., Phragmites australis, and Juncus roemerianus. High-resolution wetland surface elevation change and accretion data were collected within this region (Fig. 2), both before and after the storm, using the SETMH method (Cahoon et al. 2002a, 2002b). These SET-MH stations were installed during the past two decades independently by several federal and non-federal agencies, nongovernmental organizations (NGOs), and academic institutions to investigate or monitor elevation dynamics in coastal wetlands (Online Resource 1). The data included in this study were collected using either the original Pipe SET method (24.2\% of SET-MH stations, Cahoon et al. 2002a) or the Rod SET method (75.8\%, Callaway et al. 2013) (see Online Resource 2). The SET-MH method was developed originally to address hypothesis-driven research questions related to processes controlling marsh surface elevation change; however, over time it has been used increasingly to monitor long-term elevation change relative to local sea-level trends. Hence, SET stations are located in wetlands best suited to address specific research questions or monitor the habitat sustainability at a specific wetland (Lynch et al. 2015). Thus, the collection of stations represents an opportunistic regional network, not a strategically planned regional network, to assess storm impacts.

Data from this opportunistic network enabled large spatialscale assessments of storm impacts and wetland responses along a gradient of impact intensity by quantifying the overall change in marsh surface elevation. A total of 1230 records were received from collaborators and the Preferred Reporting Items for Systematic Reviews and Meta-Analyses (PRISMA) approach (Moher et al. 2009) was used for identifying, screening, and determining eligibility of SET-MH stations (Fig. 3). Data were excluded at three stages in the PRISMA process: (1) records were screened to determine if they met our initial criteria (unique record, within study region

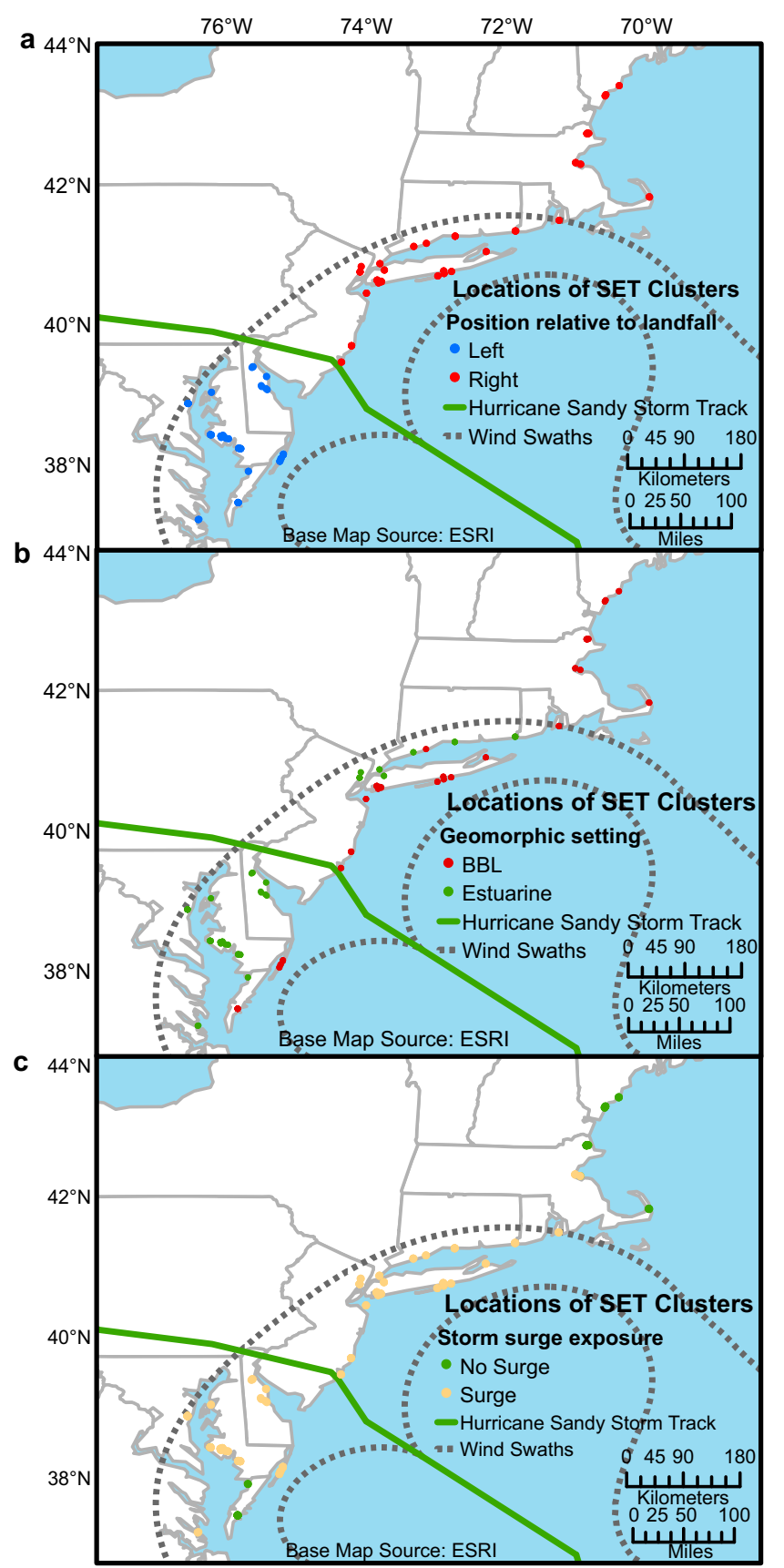

Fig. 2 Maps of study region showing storm track, wind swaths (34 knot and $64 \mathrm{kn}$ ) and clusters of SET stations representing 223 unique SETs with eligible surface elevation table (SET) data in each category: a position relative to landfall (left or right), b geomorphic setting (backbarrier lagoon [BBL] or estuarine), and $\mathbf{c}$ storm surge (no surge or surge). Storm track and wind swath shapefiles from the National Oceanic and Atmospheric Administration (2014)

and target community, and intact benchmark); (2) for each remaining record, we determined the availability of data and records were excluded if data were not provided by collaborators; and (3) SET-MH data were assessed for eligibility based on exposure to experimental treatments, pre- and poststorm record and data anomalies (Fig. 3). A total of 965 SET- 
MH stations met our initial criteria and, of these, 223 stations had data suitable for inclusion in our analyses. All elevation data used in this study came from SET-MH stations that met the following criteria: within estuarine emergent marsh located between Virginia and Maine (inclusive), was not exposed to experimental treatments, had at least three years in the prestorm record, was measured within one year following Hurricane Sandy (October 2012-October 2013; frequency distribution of post-storm measurement dates can be found in Online Resource 3), and the post-storm measurement was taken within the same season as the pre-storm record. To minimize seasonal variation, we used data from one eligible season per SET (either winter/spring or summer/autumn); thus, measurement season was consistent within a specific station, but varied among stations. We identified two SET stations with large outliers, one inconsistent pre-Sandy trend (Plum Island, MA) and one large post-storm deviation from expected (Delaware Bay). Plum Island experienced two large deposition events, causing poor fit of long-term trends, and artificially inflating the post-storm deviation datum. The Delaware Bay station had a post-storm deviation of $138 \mathrm{~mm}$ from expected. As we had insufficient representation spanning this gap, and these outliers were likely to have considerable pull on parameter estimates, we removed them from our analysis. Eligible accretion data (i.e., $\mathrm{MH}$ ) were missing from 66 of these 223 SET-MH stations, which limited the data available to evaluate our hypotheses, so our analyses were conducted only on the elevation data from SETs.

\section{Structural Equation Modeling}

We developed a multivariate hypothesis for evaluation using the available data and structural equation modeling (Grace 2006). A central part of our hypothesis is that differences in physical drivers of storm surge extent and duration on either side of a storm's point of landfall and within different

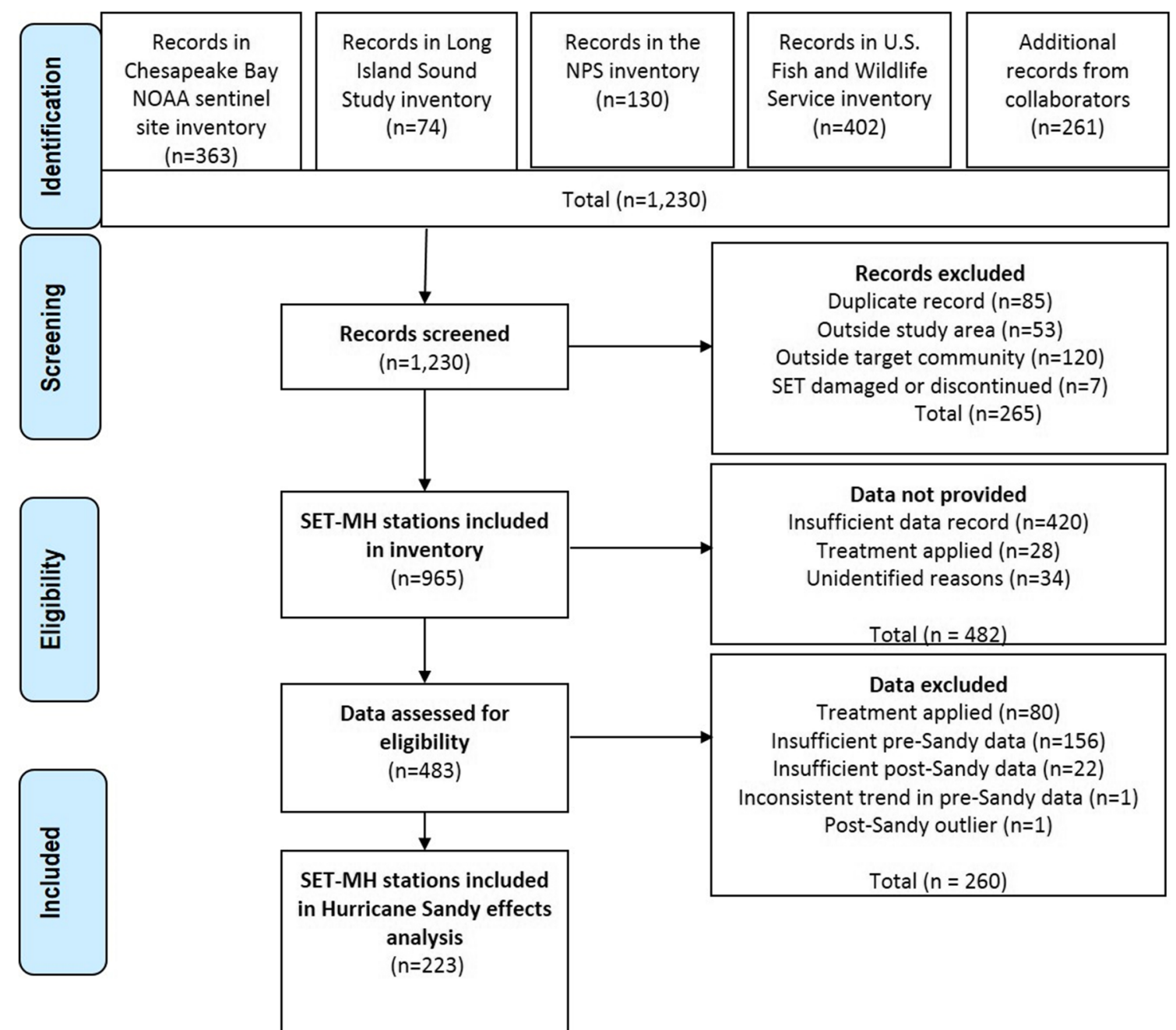

Fig. 3 Preferred Reporting Items for Systematic Reviews and MetaAnalyses (PRISMA) flow diagram detailing the omission of surface elevation table-marker horizon (SET-MH) records from the inventory and the Hurricane Sandy effects analysis. Records are removed from the tally as you move down the flow diagram and the list within each box. NOAA National Oceanic and Atmospheric Administration, NPS National Park Service; $n=$ number of SET-MH stations 
geomorphic settings could differentially influence the coastal marsh processes related to sediment deposition, sediment erosion, soil compaction (from storm surge water overburden), and ultimately marsh surface elevation change (Cahoon 2006). Based on the physical characteristics of Hurricane Sandy, we used existing knowledge to develop an initial structural equation model (SE model) describing the processes driving marsh surface elevation change (Fig. 4). SEM is a methodology designed to address questions about complex systems; it is best understood as a framework for quantitative analysis that uses statistical techniques rather than a statistical method itself, and one that permits the evaluation of networks of direct and indirect effects (Grace et al. 2012). The SEM approach used in this study examines both direct and indirect influences on marsh surface elevation change. Variables representing storm exposure and intensity (e.g., distance from landfall and position relative to storm landfall [left or right]), and geomorphic setting are predicted to directly influence both presence of storm surge and marsh surface elevation change. Additional variables that may account for otherwise unexplained variance (e.g., the rate and variation in pre-storm surface elevation change) are not predicted to influence storm surge exposure and are therefore included only as possible direct effects on marsh surface elevation change. The surface elevation change model and storm surge sub-model in Fig. 4 (hypothetical model) were analyzed separately using a piecewise approach to model estimation and evaluation using R version 3.3.1 (Grace et al. 2012; R Core Team 2016). This approach allowed us to choose from a broader array of tools for evaluating each component of the overall model. Corrected Akaike's Information Criterion (AICc; Burnham and Anderson 2002) was used for comparing candidate models chosen for interpretation.

\section{Elevation Response Variable}

Post-storm deviation from the expected surface elevation change trend was used as the measure of Hurricane Sandy effect on marsh surface elevation. We first calculated a pre-storm trend for each SET by fitting a regression line to the pre-storm total elevation change measurements using $\mathrm{R}$ version 3.3.1 (R Core Team 2016). We extended this regression line one year beyond the date that Hurricane Sandy made landfall and measured the residual distance from this line to the post-storm total elevation change measurement using a distance to line $\mathrm{R}$ function developed by Bourke (2015). Total surface elevation change is the mean change in pin height since baseline, at each survey interval for each SET (28-36 pin measurements). See Online Resource 4 for an example of this procedure.

\section{Predictor Variables}

The predictor variables fell into two categories: (1) variables representing storm exposure and intensity, and (2) variables

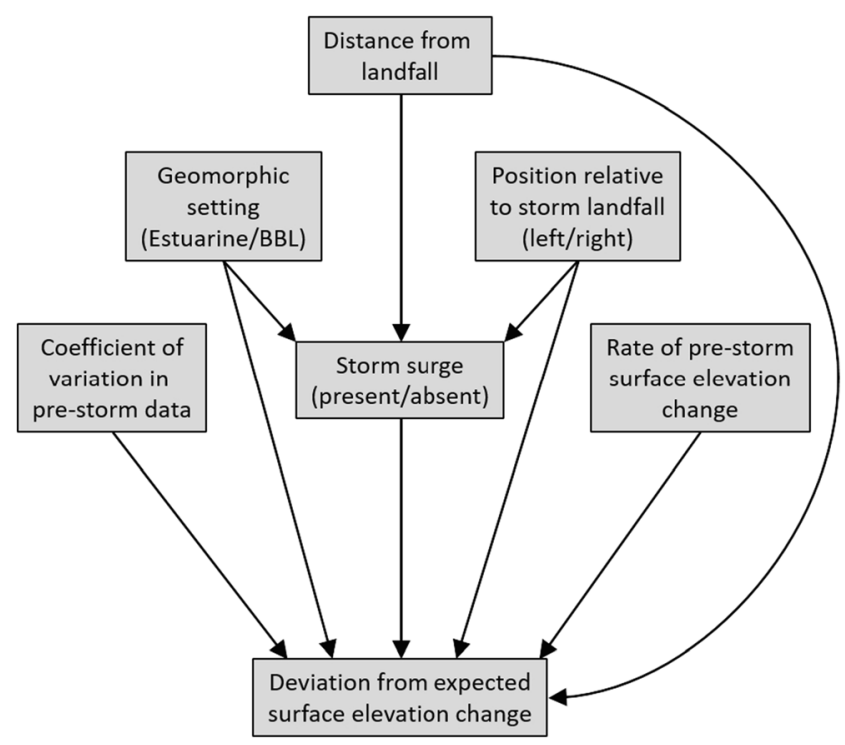

Fig. 4 Initial structural equation model illustrating hypothesized links between predictor variables and response variables. Exogenous/external predictors include distance to landfall, geomorphic setting (estuarine or back-barrier lagoon $[\mathrm{BBL}]$ ), position relative to landfall (left or right), coefficient of variation in pre-storm data, and rate of pre-storm elevation change. Exposure to storm surge was hypothesized to be a key mediator variable in the model

that may account for additional variance in the deviation from expected surface elevation change post-storm.

Variables representing storm exposure and intensity include distance from storm landfall, position relative to storm landfall, geomorphic setting, and exposure to storm surge (within or outside surge zone) (Fig. 2). We calculated distance from SET station to storm landfall $\left(39.4^{\circ} \mathrm{N}, 74.4^{\circ} \mathrm{W}\right.$; Blake et al. 2013) using the sp package in $\mathrm{R}$ version 3.3.1 (Pebesma and Bivand 2005; Bivand et al. 2013; R Core Team 2016). Distance was calculated in kilometers and was scaled prior to analysis to increase similarity with the magnitude of other predictors $($ dist. $=$ distance to landfall/1000).

Position relative to landfall was assigned as those to the left (south) or those to the right (north) of storm landfall $\left(39.4^{\circ} \mathrm{N}\right.$, $74.4^{\circ} \mathrm{W}$; Blake et al. 2013; Fig. 2a). Stations to the left or right were assigned a 1 or 0 , respectively, during analysis. This variable represents a complex array of processes. Different physical characteristics between the two positions include, but are not restricted to, wind intensity and direction, movement of water and surge retention time, geomorphic setting, and differences in underlying parent material which may have implications for sediment transport and trapping (Stevenson et al. 1988).

Stations were assigned to one of two potential geomorphic settings: (1) estuarine marsh and (2) back-barrier lagoonal (BBL) marsh (Cahoon et al. 2009; see Online Resource 5 for descriptions of geomorphic setting categories). Stations within estuaries that flowed into back-barrier lagoons were included in the latter category, as the barrier island was likely 
to influence storm surge timing and severity. Stations within estuaries and those within back-barrier lagoons were assigned a 1 or 0 , respectively, during analysis.

Storm surge area was obtained from the Hurricane Sandy Impact Analysis-Federal Emergency Management Agency (FEMA) Modeling Task Force (Federal Emergency Management Agency 2015). As high-resolution data did not cover the entire study region, we used the Medium and Low Resolution Storm Surge Extent (Interim 30-meter Storm Surge Extent 110112) in ArcGIS 10.1 to assign a storm surge category (present/absent). Stations that were assigned to the storm-surge-absent category were then visually examined and reassigned if needed (Online Resource 6 provides details on reassigned stations). Stations exposed to (present) and those not exposed to (absent) the storm surge were assigned a 1 or 0 , respectively, during analysis.

Additional variables to account for unexplained variance include both the coefficient of variation and the rate of change in the pre-storm record. Coefficient of variation (CV) of the residual distance from the pre-storm elevation trend line was calculated using the formula: $\mathrm{CV}=($ standard deviation $\times 100) /$ mean residual distance of pre-storm measurements per SET. This metric indicates the natural long-term variation at the site. Rate of change was extracted from the regression line predicted by the pre-storm total elevation change measurements used to calculate the elevation response variable. This metric was used as an indication of long-term trends in marsh elevation change.

We used generalized variance inflation factor analysis (VIF) to assess the co-linearity between predictor variables using the car package in R version 3.3.1 (Zuur et al. 2009; Fox and Weisberg 2011; R Core Team 2016). Variables with a VIF $>3$ are generally considered to have high co-linearity. Additionally, we generated bivariate plots to visualize correlations between predictor variables.

\section{Model Building}

We hypothesized there would be a nonlinear response to distance to storm landfall by both response variables (deviation from expected and presence of storm surge). For this reason, we compared models containing a linear distance curve with those containing a quadratic distance curve in order to determine the best base model for each response variable (deviation from expected change and storm surge presence).

To determine the best model for deviation from expected elevation change, a logical subset of all possible models was assessed. All candidate models included distance to storm landfall and predictor variables were added to this base model consistent with a model building approach. Model complexity was increased with each additional predictor added, until all main effects were included in a full model. In each step, variable addition was based on the degree of correlation between the residuals from the previous model and the remaining predictor variables. Interactions between distance to storm landfall and all other variables, and between geomorphic setting and all other variables were then considered and added to the full model. To manage model complexity and guard against overfitting, models only included one interaction at a time. Main effects were retained along with significant interaction terms. The main effects were examined in each interaction model and the variable with the greatest $P$ value was removed from the subsequent model. This process was repeated on the simplified model and continued until all main effects were either present in an interaction or had a $P$ value of $<0.05$. A total of 46 scientifically plausible candidate models were developed through this process for multi-model comparison (Online Resource 7).

For the storm surge sub-model, all models included distance to storm landfall. Position relative to landfall and geomorphic setting were included as main effects and in interaction with the distance variable. No models included both categorical predictor variables. A total of five models were included in the storm surge sub-model list (Online Resource 7).

\section{Model Assessment}

Model assessment ensured a consideration of all possible linkages, with evaluations based on AICc (Burnham and Anderson 2002). Candidate models for each response variable were ranked using their AICc value. We calculated the difference in $\mathrm{AICc}(\triangle \mathrm{AICc})$ from the lowest $\mathrm{AICc}$ value $\left(\mathrm{AICc}_{\min }\right)$ for each candidate model $\left(\mathrm{AICc}_{\mathrm{i}}\right)$ using the formula $\triangle \mathrm{AICc}=$ $\mathrm{AICc}_{\mathrm{i}}-\mathrm{AICc}_{\text {min }}$. Models with $\triangle \mathrm{AICc}<2$ were considered equivalent (Burnham and Anderson 2002). The simplest model with the lowest AICc within this top model list was considered the best model and its parameter estimates were used for interpretation. Models were compared using the AICcmodavg package in $\mathrm{R}$ version 3.3.1 (Mazerolle 2016; R Core Team 2016).

\section{Spatial Autocorrelation}

Spatial autocorrelation occurs when the residuals of data points that are spatially close together are not independent (Bivand et al. 2013). We used Moran's I to statistically test for residual spatial autocorrelation in the deviation from expected response variable using the spdep package in R version 3.3.1 (Bivand and Piras 2015; R Core Team 2016). Spatial autocorrelation was assessed on links between seven neighboring pairs $(k=7)$. Weights were standardized by row, where weights were divided by the row sum $($ style $=\mathrm{W})$. Since spatial autocorrelation was detected, we calculated the effective sample size $\left(n_{\text {eff }}=n /(1+\right.$ absolute Moran's $I$ statistic estimate)) and adjusted the $\mathrm{AICc}$ values for all top models, adjusted AICc values 
$\mathrm{AICc}_{\text {adj }}=\left(\mathrm{AIC}+\left((2 K(K+1)) / n_{\text {eff }}-K-1\right)\right)$, and adjusted summary statistics for predictors in the best deviation from expected model and storm surge sub-model.

\section{Statistical Programs and Packages Used}

All analyses were conducted, and graphics were created, using $\mathrm{R}$ version 3.3.1 ( $\mathrm{R}$ Core Team 2016) and ArcGIS 10.4. The following $\mathrm{R}$ packages were used during data formatting: reshape2 (Wickham 2007), plyr (Wickham 2014), and data.table (Dowle et al. 2015).

\section{Results}

\section{Correlation Between Predictor Variables}

The VIF values were less than three for all predictors in both the deviation from expected and storm surge models. This result obviates concerns about inflation of standard errors for parameter estimates resulting from multicollinearity. A table of VIF values and bivariate plots between predictor variable is available in Online Resource 8.

\section{Distribution of SET-MH Stations Used in Effects Analysis}

A number of factors contribute to the distribution of sampling in large spatial datasets, resulting in uneven dispersion of replicates among geographic and geomorphic settings. In this study, some of these spatial factors include the opportunistic nature of the SET-MH network, the distribution of geomorphic settings along the east coast from Virginia to Maine, and the location of Hurricane Sandy landfall (Fig. 2). The distribution of eligible SET stations between geomorphic settings, position relative to storm landfall, and distance from storm landfall (Table 1 and Fig. 2) shows that the majority of stations within back-barrier lagoonal marsh were located to the right of landfall $(78 \%)$ and the majority of stations within estuarine marsh were located to the left of landfall (73\%). SET stations occur from $8 \mathrm{~km}$ to as much as $557 \mathrm{~km}$ from the storm landfall (Table 1).

\section{Deviation from Expected Surface Elevation Change Model}

The model with the lowest AICc value (1758.71) included a quadratic curve relationship between deviation from expected surface elevation change and distance from storm landfall. The model based on a linear relationship was greater than two points higher than this $\mathrm{AICc}_{\min }$ model $(\triangle \mathrm{AICc}=21.34$; Online Resource 9). Therefore, all models were designed to accommodate a quadratic distance curve.
Three of 46 models had a $\triangle \mathrm{AICc}$ less than 2 from the $\mathrm{AICc}_{\min }$ model (Online Resource 9), and thus are statistically equivalent. The simplest model was model $15 \mathrm{e}$, which included an interaction between distance from and position relative to landfall, but no other predictors (Online Resource 9). See Online Resource 10 for model summary information and model predicted versus response plot. Model $15 \mathrm{e}$ was determined to be the best model available for predicting deviation from expected surface elevation change following Hurricane Sandy, where model 15e includes distance from landfall, position relative to landfall, and their interaction.

As deviation from the expected surface elevation change trend was spatially autocorrelated $(P<0.001, \mathrm{SD}=7.89)$, we calculated effective sample size and used this to calculate an adjusted AICc value for the three top models (Online Resource 9). Although the $\triangle \mathrm{AICc}$ based on the adjusted values $(\triangle \mathrm{AICc}$ for model $15 \mathrm{c}=0.625$ and model $15 \mathrm{e}=$ $0.633)$ differed from the unadjusted values $(\triangle \mathrm{AICc}=0.67$ and 0.681 , respectively), the order did not change.

Parameter estimates from model $15 \mathrm{e}$ (best model) indicate that within approximately $200 \mathrm{~km}$ from storm landfall there was a greater negative deviation from the expected elevation change trend (elevation loss) and a greater effect of distance to landfall in stations to the right of landfall than to the left (Fig. 5, Online Resource 10).

Of the 223 eligible SET stations, there were 125 stations $(56.1 \%)$ with a deviation greater than expected (elevation gain) and 98 stations (43.9\%) with a deviation less than expected (elevation loss; Fig. 6a). Stations with the greatest elevation loss were located to the right of landfall, whereas stations that experienced the greatest elevation gain were to the left of landfall (Fig. 7, Table 2). The range in deviation from the expected elevation change trend was greater to the right of landfall than to the left $(113.2$ and $88.8 \mathrm{~mm}$, respectively; Table 2). To the right of landfall there were greater negative values (elevation loss) than to the left (minimum $=-69.4$ [Forsythe National Wildlife Refuge, NJ] and $-28.8 \mathrm{~mm}$ [Delaware Bay, DE], respectively) and the maximum positive value (elevation gain) was lower to the right than to the left of landfall (maximum $=43.8$ [Fire Island National Seashore, $\mathrm{NY}$ ] and $60.0 \mathrm{~mm}$ [Delaware Bay, DE], respectively, Fig. 7).

Owing to yearly variation among surveys, we expected that post-storm measurements would exhibit some deviation from the expected change trend, irrespective of hurricane influence. Post-storm residual distance from the pre-storm trend line (Fig. 6a) and pre-storm mean residual distance (Fig. 6b) was less than or equal to $\pm 5 \mathrm{~mm}$ for $62.8 \%$ and $89.7 \%$ of eligible SET stations, respectively, indicating greater variation in the residual distance (in other words, exceeding $\pm 5 \mathrm{~mm}$ ) poststorm. Based on these distributions, we suggest that a deviation of greater than $5 \mathrm{~mm}$ from expected is more likely to indicate an effect of Hurricane Sandy on the rate of elevation change than a deviation of less than $5 \mathrm{~mm}$. If we look at the 
Table 1 Number of SET stations used in analyses and distance to storm landfall (min., max., and range) for each unique geomorphic and geographic location category. Categories based on geomorphic setting (back-barrier lagoon, estuarine) and position relative to landfall (left, right)

\begin{tabular}{|c|c|c|c|c|c|c|}
\hline \multirow[t]{2}{*}{ Data } & \multirow[t]{2}{*}{ Descriptor } & \multicolumn{2}{|c|}{ Back-barrier lagoon } & \multicolumn{2}{|l|}{ Estuarine } & \multirow[t]{2}{*}{ Total } \\
\hline & & Left of landfall & Right of landfall & Left of landfall & Right of landfall & \\
\hline SET & No. SET stations & 26 & 90 & 78 & 29 & 223 \\
\hline SET & Min. dist. (km) & 154.5 & 8.0 & 90.0 & 152.3 & \\
\hline SET & Max. dist. (km) & 249.0 & 557.1 & 298.9 & 303.9 & \\
\hline SET & Range dist. (km) & 94.6 & 549.1 & 208.9 & 151.6 & \\
\hline
\end{tabular}

stations with a greater than $5 \mathrm{~mm}$ deviation from expected, we find that stations to the left of landfall were more likely to experience a greater than expected elevation change (27 stations; $77.1 \%$ ) than a less than expected change (8 stations; 22.9\%; Fig. 7a; Table 2). This trend was also evident in the range and mean deviation from expected values exhibited to the left of landfall (range $=-28.8$ to $60.0 \mathrm{~mm}$; mean loss $=-$ $15.9 \pm 3.6 \mathrm{~mm}$; mean gain $=18.0 \pm 2.4 \mathrm{~mm}$; Table 2$)$. This suggests elevation gain was more prevalent than elevation loss in stations located to the left of landfall. To the right of landfall, the proportion of stations with greater than expected change was similar to those with less than expected change (28 stations $(58.3 \%)$ and 20 stations $(41.7 \%)$, respectively; Fig. 7b; Table 2). Stations to the right tended to experience greater elevation loss than elevation gain relative to pre-storm trend predictions (range $=-69.4$ to $43.8 \mathrm{~mm}$; mean loss $=-$ $19.7 \pm 4.8 \mathrm{~mm}$; mean gain $=10.9 \pm 1.6 \mathrm{~mm}$; Table 2 ).

\section{Storm Surge Sub-model}

The model that assumed a linear relation between storm surge and distance from storm landfall had the lowest AICc value (145.04). Even though the model containing the quadratic relation had a $\triangle \mathrm{AICc}$ less than two $(\triangle \mathrm{AICc}=0.94$; Online Resource 9), the linear relation was included in all storm surge sub-models for simplicity.

Two of five storm surge models had a $\triangle \mathrm{AICc}$ less than two from the $\mathrm{AICc}_{\min }$ model (Online Resource 9) for predicting presence of storm surge. The simplest model was sub-model 3 , which consisted of distance from, and position relative to, landfall with no interaction (Online Resource 9). Therefore, sub-model 3 was considered the best model available for predicting storm surge presence during Hurricane Sandy. See Online Resource 10 for model summary information.

We calculated effective sample size and used this to calculate an adjusted AICc value for the two models with the lowest AICc value (Online Resource 9). The $\triangle \mathrm{AICc}$ based on the adjusted sample size $(\triangle \mathrm{AICc}=1.31)$ was greater than the unadjusted value $(\triangle \mathrm{AICc}=1.27)$; however, the order did not change (Online Resource 9).

Based on sub-model 3 (best model), the probability that a station was exposed to the storm surge was predicted to decrease with increasing distance from landfall (Fig. 8, Online Resource 10). Sub-model 3 also predicted a shorter distance of influence to the left of landfall than to the right (Fig. 8, Online Resource 10).
Fig. 5 Graph of post-storm deviation from expected surface elevation change along the distance to storm landfall gradient (kilometers). Lines are parameter estimates, from the best model (Online Resource 10), for stations to the right (closed circle, solid line) and left (open circle, dashed line) of storm landfall. Dotted gray line indicates null expectation. Solid gray line indicates $200 \mathrm{~km}$ from landfall. Only eligible surface elevation data are displayed and used in analysis (223 surface elevation table stations)

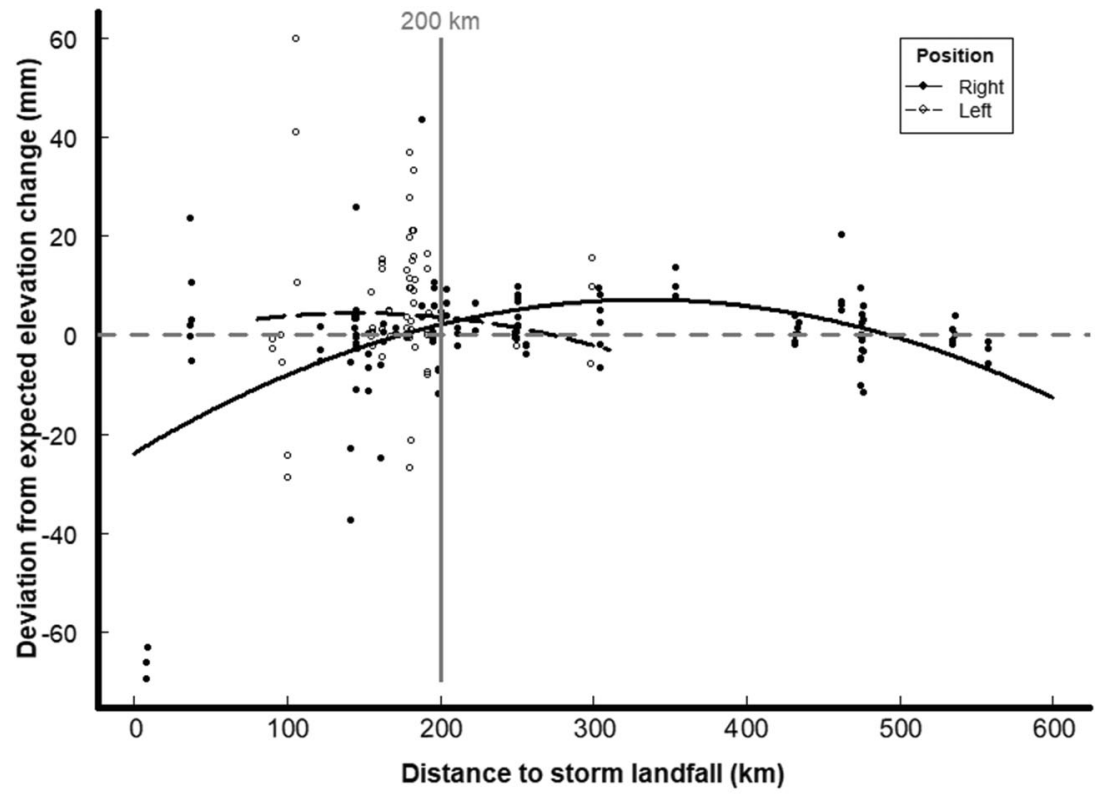



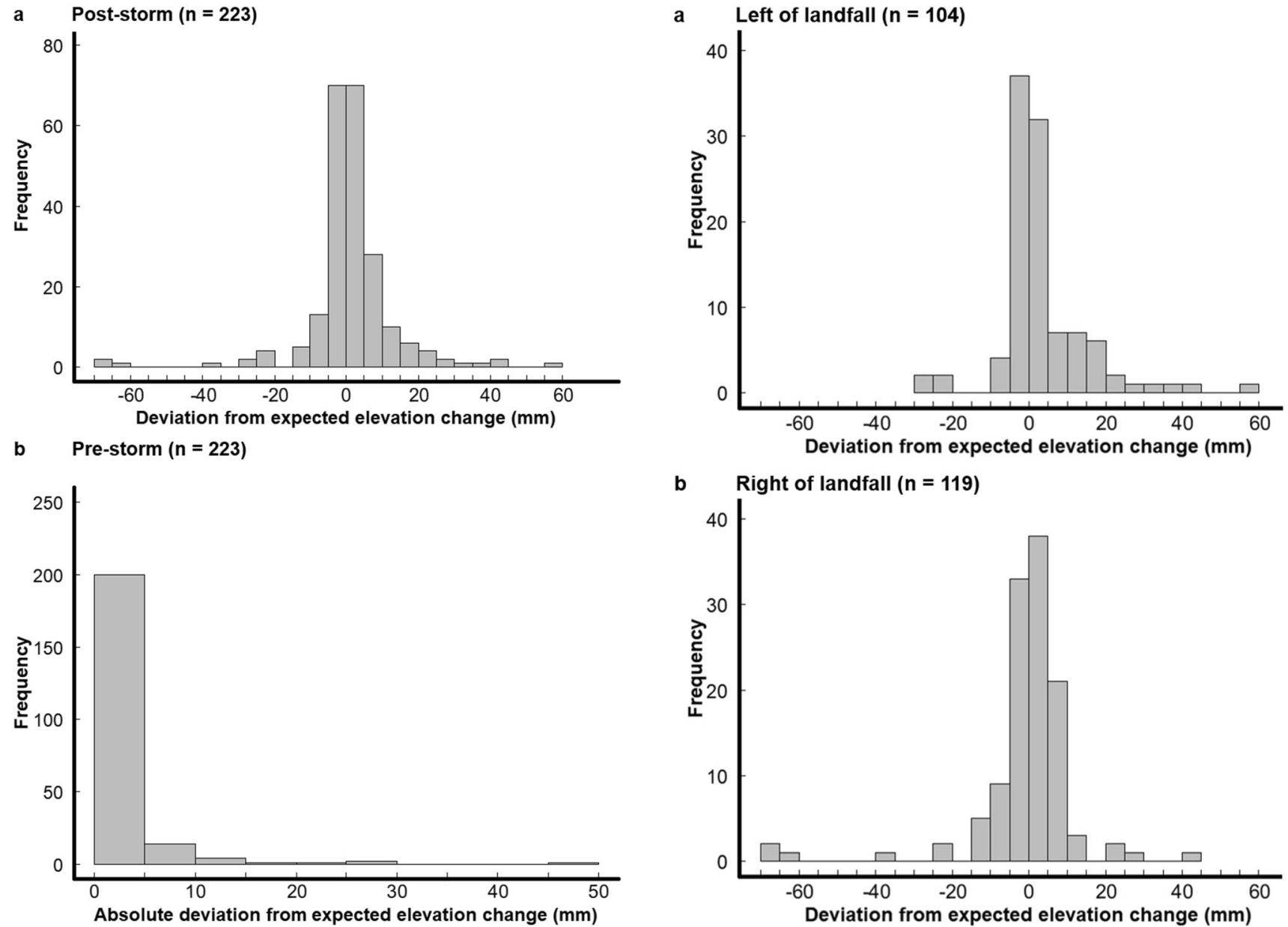

Fig. 6 Frequency distribution of a post-storm residual distance from expected $(\mathrm{mm}, \pm)$ and $\mathbf{b}$ pre-storm mean residual distance $(\mathrm{mm}$, absolute) using all eligible surface elevation table data $(n=223)$

The omission of storm surge from the best deviationfrom-expected-change model may reflect the variation in direction (loss or gain) more than the magnitude of the effect. There were a greater number of eligible SET

Fig. 7 Frequency distribution of post-storm residual distance from expected for surface elevation table stations to the $\mathbf{a}$ left and $\mathbf{b}$ right of landfall

stations with storm surge present than absent (175 and 48, respectively; Fig. 9). The deviation from the expected elevation change trend had both greater positive (elevation gain) and negative (elevation loss) values and

Table 2 Summary information for stations with a deviation from expected elevation change greater than $\pm 5 \mathrm{~mm}$. Number of stations (N) with elevation gain and loss in each position relative to landfall category (all stations, left, right), along with the maximum value, mean and standard error (SE) are included

\begin{tabular}{|c|c|c|c|c|}
\hline Position & Direction of elevation effect & $N(\%)$ & $\begin{array}{l}\text { Maximum } \\
\text { deviation (mm) }\end{array}$ & Mean $\pm \mathrm{SE}(\mathrm{mm})$ \\
\hline \multirow[t]{2}{*}{ All } & Gain & $55(66.3 \%)$ & 60.0 & $14.4 \pm 1.5$ \\
\hline & Loss & $28(33.7 \%)$ & -69.4 & $-18.6 \pm 3.6$ \\
\hline \multirow[t]{2}{*}{ Left } & Gain & $27(77.1 \%)$ & 60.0 & $18.0 \pm 2.4$ \\
\hline & Loss & $8(22.9 \%)$ & -28.8 & $-15.9 \pm 3.6$ \\
\hline \multirow[t]{2}{*}{ Right } & Gain & $28(58.3 \%)$ & 43.8 & $10.9 \pm 1.6$ \\
\hline & Loss & $20(41.7 \%)$ & -69.4 & $-19.7 \pm 4.8$ \\
\hline \multirow[t]{2}{*}{ Storm surge } & Gain & $103(58.9 \%)$ & 60.0 & $7.9 \pm 1.0$ \\
\hline & Loss & $72(41.1 \%)$ & -69.4 & $-7.5 \pm 1.7$ \\
\hline \multirow[t]{2}{*}{ No storm surge } & Gain & $22(45.8 \%)$ & 20.4 & $4.3 \pm 1.1$ \\
\hline & Loss & $26(54.2 \%)$ & -11.5 & $-2.5 \pm 0.6$ \\
\hline
\end{tabular}




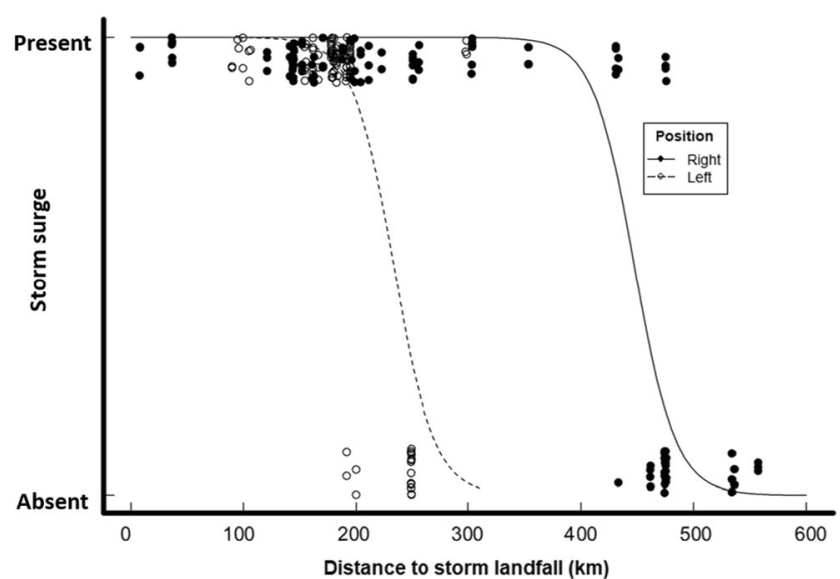

Fig. 8 Storm surge presence (1) or absence (0) along the distance from landfall gradient. Lines are predicted probability values from the best submodel (sub-model 3) for stations to the right (closed circle, solid line) and left (open circle, dashed line) of storm landfall. Data and models are based on eligible surface elevation data (223 surface elevation table stations). Points are randomly jittered along the vertical axis for visibility of overlapping points

greater mean values at stations exposed to the Hurricane Sandy storm surge (range $=-69.4$ to $60.0 \mathrm{~mm}$, mean gain $=7.9 \pm 1.0 \mathrm{~mm}$, mean loss $=-7.5 \pm 1.7 \mathrm{~mm}$ ) than those outside storm surge influence (range $=-$ 11.5 to $20.4 \mathrm{~mm}$, mean gain $=4.3 \pm 1.1 \mathrm{~mm}$, mean loss $=-2.5 \pm 0.6 \mathrm{~mm}$, Table 2). There was a greater percentage of stations within the $\pm 5 \mathrm{~mm}$ deviation from the expected change trend in areas that storm surge was absent from than present $(77.1 \%$ and $58.9 \%$, respectively; Fig. 9). This suggests that even though storm surge tended to increase the magnitude of deviation from expected, it had a complex influence on marsh surface elevation change, resulting in both loss and gain, which may explain the absence of this effect in model selection.

\section{Structural Equation Model Selected for Interpretation}

We used the best deviation-from-expected surface elevation change model and storm surge sub-model to create a revised SE model (Fig. 10; compare with initial model in Fig. 4). Distance from landfall $(-0.71)$ and position relative to landfall $(-0.16)$ were found to explain the likelihood of storm surge presence in the SET data. Observed storm surge presence or absence, however, did not help explain deviation from the expected surface elevation change trend. Rather, deviation from expected elevation change was explained by the interaction between distance from landfall and position relative to landfall (see, e.g., Figs. 4 and 6). Furthermore, geomorphic setting, coefficient of variation in pre-storm elevation trend, and rate of pre-storm elevation trend had no significant effect on the deviation from the expected elevation change.

\section{Discussion}

\section{Spatial Variation in Storm Impacts}

Understanding the impact of Hurricane Sandy on coastal wetland surface elevation change requires knowledge of both the physical characteristics of the storm and its interaction with the coastal landforms it encounters. There are important landform differences in coastal geomorphology and wetland setting on either side of the point of landfall at Brigantine, NJ. To the right of landfall the predominant wetland type is backbarrier marsh, whereas to the left it is predominantly estuarine

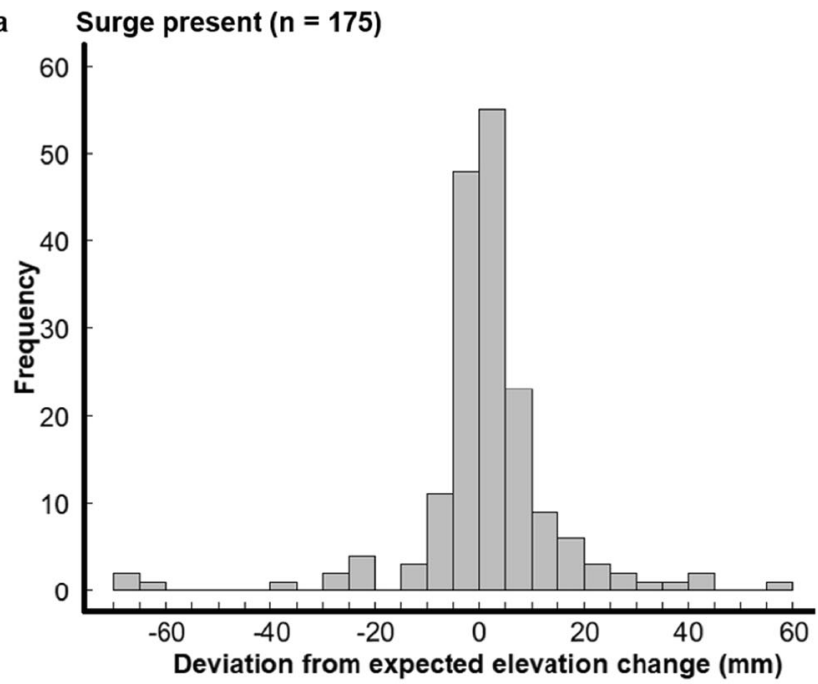

b

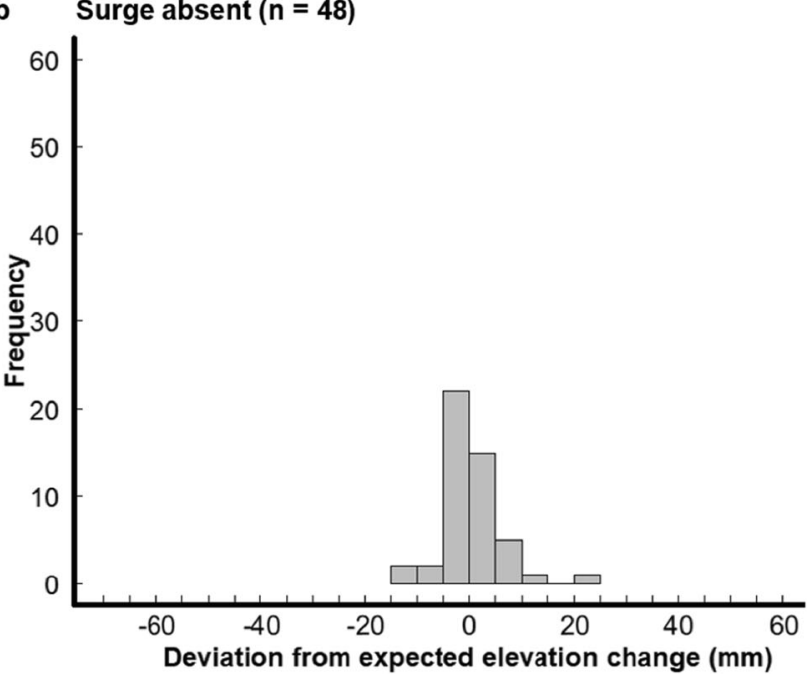

Fig. 9 Frequency distribution of post-storm residual distance from expected for eligible surface elevation table stations with storm surge a present and $\mathbf{b}$ absent 


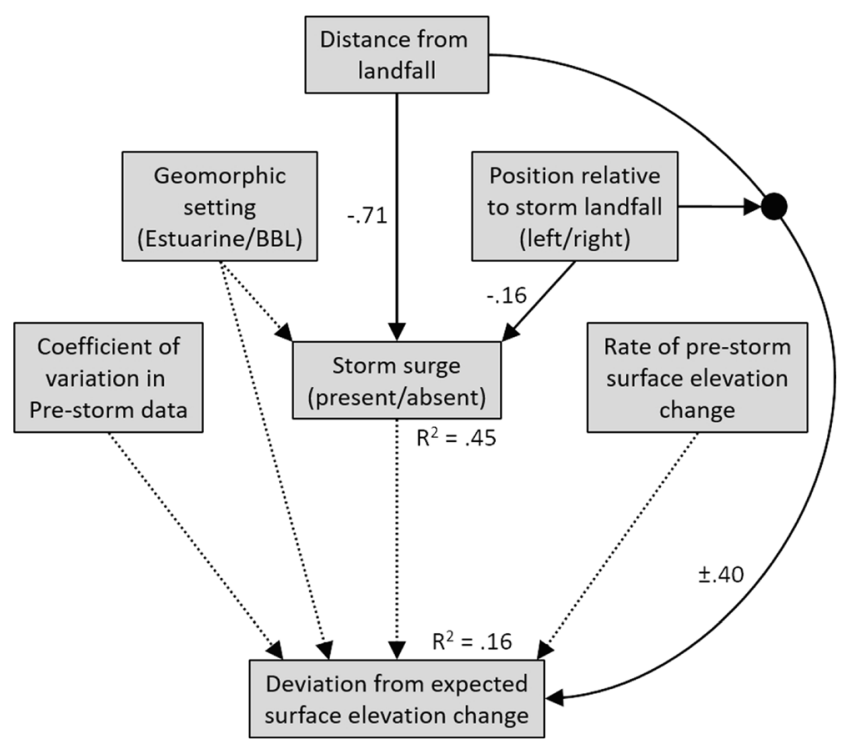

Fig. 10 Revised surface elevation model. Solid lines represent pathways among predictors present in the best deviation from expected model (model 15e) and storm surge sub-model (sub-model 3). Dashed lines represent hypothesized pathways that were not supported in the best models. Simple standardized effect estimates are presented on the graph for non-interacting relationships and for the combined effect of the interactive influence of distance from landfall and position relative to storm landfall (indicated by the line from the solid dot to deviation from expected surface elevation change)

marsh along tidal tributaries of Delaware Bay and Chesapeake Bay. Even though marsh settings are separated geographically, wetland type did not influence marsh elevation trends or the presence of storm surge (Fig. 10). The spatial characteristics of the storm apparently overwhelmed any influence that wetland geomorphic setting had on storm impact. Hurricane Sandy's physical characteristics meant that storm surge area was more extensive right of the landfall in the northeast quadrant of the storm, than left of the landfall where winds switched from out of the northwest to out of the southwest during storm approach and passage (Dennison et al. 2012; Middleton 2016; see Fig. 1). This difference in surge dynamics resulted in important differences in wetland impacts to the right and left of the landfall point. The smaller surge area to the left of landfall indicates a shorter distance of surge influence compared with the right of landfall (Fig. 8). In addition, stations to the left of the storm landfall were considerably further away from this position than stations to the right (Fig. 2, Table 1). To the left of landfall, elevation gain relative to pre-storm predictions was more prevalent than elevation loss, and the greatest elevation gains for the northeast region were found in these stations. To the right of landfall, stations experienced the greatest elevation loss and range in deviation from expected, and the maximum elevation gains were lower than stations to the left. These effects appear to be the result of the interaction between distance from and position relative to landfall as shown in the SE model (Fig. 10). This finding is supported by a remote-sensing study of Hurricane Sandy's storm surge impact on salt marsh condition (Rangoonwala et al. 2016), where salt marshes located within $200 \mathrm{~km}$ right (north) of landfall experienced high surge persistence and high salt marsh condition change compared with marshes farther north of the storm track.

Rapid assessment of Hurricane Sandy impacts based on qualitative visual observations made in the weeks immediately following the storm revealed low levels of physical impacts to coastal marshes in general across the northeast region (American Littoral Society 2012; Grubel et al. 2012; Dennison et al. 2012) and our results found that approximately $63 \%$ of SET-MH stations experienced an elevation change that was within the expected range of variability of prestorm trends ( $5 \mathrm{~mm}$ deviation from trend). Along the shores of New Jersey, Long Island Sound, and New York HarborRaritan-Jamaica Bays, 14-17\% of marshes experienced moderate levels of physical damage whereas $54-64 \%$ of marshes experienced low levels of physical damage (American Littoral Society 2012). Only a few marshes exhibited high levels of physical impacts (e.g., Little Egg Harbor). Typically, wrack deposits were visible at the marsh upland edge in many back-bay marsh areas, but not in the marsh itself. Marshedge erosion was observed in some locations (e.g., Barnegat Bay marshes located at the point of landfall; Martha Maxwell-Doyle, Barnegat Bay Partnership, personal commun., May 18, 2017), but no quantitative data were available to evaluate its extent across the region. A geographic information system (GIS) analysis of Hurricane Sandy impacts to coastal wetlands of New Jersey revealed that salt marshes were impacted by either erosion or sediment deposition (Hauser et al. 2015). Although such visual observations can be useful, they also can be misleading because they do not account for the storm's influence on subsurface processes such as shallow subsidence or shallow expansion (e.g., root zone expansion from enhanced root zone growth or dilation water storage), which can vary widely among sites and storms and are often the dominant control on elevation change (Cahoon 2006). For example, a review of major storm impacts revealed that when compaction related to storm surge occurred, it ranged from 3 to $33 \mathrm{~mm}$ (Cahoon 2006).

In an empirical, quantitative evaluation of three marshes in Delaware Bay left of landfall and three marshes in Barnegat Bay right of landfall where SET-MH sampling stations had been established 1.5 years prior to Hurricane Sandy, Quirk (2016) found little evidence of widespread wrack, sediment deposition, or vegetation removal on the marsh surface. Over the post-storm period, Quirk (2016) reported that surface accretion/erosion was within the range of variability prior to the storm in all six marshes. Surface elevation change over the post-storm period was within the range of variability of pre-storm trends for four of the six marshes, with one of the remaining marshes exhibiting 
significant shallow expansion and the other significant shallow subsidence (Quirk 2016). Similar storm surge effects on sediment deposition processes were observed in 1989 by Gardner et al. (1991, 1992) in a South Carolina salt marsh impacted by Hurricane Hugo, a category 4 storm whose approach was perpendicular to the shore. Mud was deposited in the forest located inland of the salt marsh, but not in the marsh itself (Gardner et al. 1991). They hypothesized that the 3-4-m-deep surge protected the marsh surface from wind, wave action, and currents. Quirk (2016) also hypothesized that much of the material carried by Hurricane Sandy flood waters passed over the marsh and was deposited along areas of taller structure than marsh grass, such as the upland-forest edge. In addition, recent investigations using large-scale experimental flumes demonstrate that vegetated marsh surfaces effectively attenuated waves and prevented erosion of the marsh surface during storm surge flooding (Moller et al. 2014; Rupprecht et al. 2017). Leonardi et al. (2018) recently reviewed the interaction between storm surge and salt marsh vegetation as it relates to surface sedimentation and erosion.

These observations may explain why surface elevation gain was lower and surface elevation loss more likely in marshes located right of landfall, where storm surge was more extensive and strongest during Hurricane Sandy. It is likely there were fewer opportunities for sediment deposition on the marsh surface and more opportunities for compaction of the marsh substrate by the overburden of the 3-4-m storm surge compared with marshes located left of landfall. It may also provide insight into why marsh surface elevation gain was more prevalent in the marshes to the left of landfall, where the surge was less extensive and less deep, such as Chesapeake Bay. In Chesapeake Bay, Dennison et al. (2012) reported that winds during Hurricane Sandy started from the northwest as the storm approached the mid-Atlantic (blowing water to the south, out of the bay) and transitioned to the southwest as the eye of the storm passed inland north of Chesapeake Bay (Fig. 1). The wind shift to the southwest blew water from the west side to the east side of Chesapeake Bay, causing wind-driven flooding on the east shore. Thus, deviation from the expected post-storm elevation trend was greater on the east side than the west side of the Chesapeake Bay $(5.4 \pm 1.7 \mathrm{~mm}$ versus $0.7 \pm 0.9 \mathrm{~mm})$. Post-storm field observations by Cahoon at Blackwater National Wildlife Refuge (NWR; east side) (Cahoon pers obs) revealed stormrelated sediment deposits on some brackish marsh surfaces along the Blackwater River that flows into Fishing Bay on the east shore of Chesapeake Bay. Apparently, sedimentladen water pushed up into the headwaters of rivers and small bays along the east shore of the bay associated with the $\sim 1-\mathrm{m}$ surge resulted in more prevalent sediment deposition and elevation gain in those marshes.

These results are consistent with the physical characteristics of Hurricane Sandy, but the range of variation in poststorm residual distance from predicted surface elevation change both left and right of the storm (Fig. 7), and in the presence and absence of storm surge (Fig. 9), indicates that a combination of factors beyond just the physics of the storm influenced wetland responses. By including both the rate of elevation change and associated variation in pre-storm data, we hoped to control for unknown differences among sites that could bias the evaluation of storm effects. We found that these variables had insubstantial impacts on elevation responses to Hurricane Sandy, perhaps due to the complex and somewhat unknown processes driving surface elevation. Some of these factors likely include sediment availability, wetland productivity and integrity, plant community structure, wetland elevation relative to mean sea level, and the degree of hydrologic alterations by human activities.

\section{Implications for Marsh Resilience}

The longer-term impacts on marsh resilience of a high-magnitude, low-frequency event like Hurricane Sandy are variable and may appear incongruous with such a physically powerful event. Although we do not know the impact of Hurricane Hugo on marsh surface elevation change throughout the entire coastline it affected, that storm had little impact on salt marsh integrity at North Inlet in South Carolina (Gardner et al. 1991, 1992). Although reports of possible vegetation dieback have been reported (e.g., Marsh et al. 2016), multiple studies have recorded minimal floristic changes following severe storm events. Rachlin et al. (2017) reported that species composition of vascular flora of salt marshes in New Jersey, New York, and Connecticut showed a high degree of stability (in other words, little change) following Hurricane Sandy. Longenecker et al. (2018) report that vegetation cover and composition were similar before and after Hurricane Sandy in a tidal marsh at Edwin B. Forsythe NWR in New Jersey, which is located at the point of landfall. In addition, Wang et al. (2017) reported a very complex pattern of accretion and erosion of marsh surfaces for salt marshes across Jamaica Bay, but eroded marsh surfaces recovered from the sediment loss after 1 year. Quirk (2016) hypothesized that Hurricane Sandy impacts on marsh surface accretion and elevation change will have little influence on longer-term elevation trends as well. Given the degree of spatial variation we found in Hurricane Sandy, surge effects on marsh elevation change, and the implications for marsh resilience to future storms also will vary spatially across the northeastern United States.

Our analyses provide inferences for storm impacts in the short term (1 year post-storm). Namely, those stations located left of landfall, compared with those on the right, experienced a greater deviation from expected elevation change, and the deviation was more likely to be positive (elevation gain). Stations to the right of landfall experienced smaller maximum deviations from expected and the deviations were more likely to be negative (elevation loss 
relative to predicted change). Although long-term inferences ( $>1$ year post-storm) cannot be drawn from our analyses, it is clear that the more prevalent gain in elevation in the marshes located left of storm landfall more likely resulted in gains in elevation capital (marsh elevation in relation to mean sea level; Reed 2002; Cahoon and Guntenspergen 2010) for those marshes. In contrast, the predominance of elevation loss in marshes to the right of landfall in the barrier island systems of northern New Jersey, New York, and Connecticut likely indicates those marshes lost elevation capital. Another potential factor contributing to elevation loss in the northern marshes to the right of landfall is that they are all built on underlying coarse-grained parent materials deposited during and immediately after the last glaciation. This has implications for sediment transport and trapping, with these northern marshes often considered sediment starved and more dependent on organic matter accumulation, which ultimately impacts long-term marsh stability (Stevenson et al. 1988). Hurricane Sandy came ashore just south of the glacial deposit line, which adds another confounding factor in understanding the interaction between the characteristics of the storm and geomorphic setting along this coastline. This complex interaction of factors likely contributed to the non-linear shape of the curve for marshes located to the right of landfall in Fig. 5, suggesting the negative impacts of the storm were greatly diminished in those marshes located greater than $200 \mathrm{~km}$ to the right of landfall.

Future coastal flood risk for the east coast of the United States will be strongly influenced by sea-level rise and changes in the frequency and intensity of tropical cyclones (Tebaldi et al. 2012; Woodruff et al. 2013; Little et al. 2015). The return period for Hurricane Sandy's flood height is predicted to decrease during the next century by a factor of up to 17-fold owing to both sea-level rise and changes in storm climatology (Lin et al. 2016). The frequency of tropical cyclones is projected to decrease although the frequency of more intense storms (category 4 and 5) is projected to increase, as is overall tropical cyclone intensity (Knutson et al. 2010; Bender et al. 2010; Peduzzi et al. 2012). For the northeastern US coast (Virginia and northward), relative sea-level rise is projected to be greater than the global average for most future global mean sea-level rise scenarios (e.g., for an intermediate scenario of $1 \mathrm{~m}$ by 2100 , this region is projected to experience an additional 0.3 to $0.5 \mathrm{~m}$ [Sweet et al. 2017]), and the midAtlantic coast of the United States is considered a hotspot of accelerated sea-level rise (Sallenger et al. 2012). Furthermore, acceleration in flooding, including minor flooding, is predicted to occur for the northeast region (Ezer and Atkinson 2014), although the existence of coastal wetlands is known to reduce flood damage to human infrastructure on the coast (Temmerman et al. 2013; Narayan et al. 2017). Thus, gains in marsh elevation capital are needed to offset the projected increases in sea level and coastal flooding frequency (Cahoon 2015), and to sustain existing marshes. Notably, as a result of Hurricane Sandy, more marshes in the Delaware Bay and Chesapeake Bay region gained short-term resilience than marshes in the New Jersey to Connecticut region. Yet, each future major storm to make landfall in the northeastern United States will have its own unique characteristics and storm surge impacts on coastal marsh elevation that will have a cumulative effect on future marsh elevation capital and resilience. The impact of each high-magnitude, low-frequency storm event (in other words, hurricanes) will be additive to the impacts of the low-magnitude, high-frequency storm events (in other words, northeaster storms) that typically occur in the northeast region of the United States each year and can generate substantial storm surges during the winter and spring (Davis and Dolan 1993; Booth et al. 2016).

\section{Conclusions}

By analyzing surface elevation data collected both before and after the storm, we were able to assess the effects of Hurricane Sandy on coastal marsh resilience across a large geographic area spanning a variety of wetland settings and storm exposures and intensities. We found that the location of marsh relative to landfall (distance and position) influenced the likelihood of inundation from storm surge and the magnitude and direction of the deviation from expected surface elevation change in the year following the storm. In addition to these findings, we found little effect of geomorphic setting (estuarine versus back-barrier lagoon) and pre-storm elevation change characteristics (rate and variation) on deviation from expected surface elevation change. As expected, storm surge strength and extent were greater to the right of landfall in the northeast quadrant of the storm, compared with the left of landfall, and marshes in these areas experienced the greatest surface elevation loss relative to expected change. Given the high degree of spatial variation found regionally in Hurricane Sandy surge effects on marsh elevation change, the implications are that marsh resilience to future storms also will vary spatially. Although hurricane's have the potential to affect the geomorphic evolution of coastal wetlands and influence the elevation of marsh surfaces, not all storms will have the same effect and not all coastal wetlands will respond similarly.

Acknowledgments We wish to acknowledge the following people and institutions that provided data in support of this project (names presented alphabetically):

Anne Giblin, Hap Garritt, Karen Sundberg, and Samantha Bond of the Plum Island Estuary Long-Term Ecological Research site, Massachusetts 
(funded by National Science Foundation [NSF] Plum Island Ecosystems - Long Term Ecological Research [PIE-LTER] 1637630 and 1238212)

Paul Castelli, Edwin B. Forsythe National Wildlife Refuge, Oceanville, New Jersey

Ben Gaspar, Rhode Island National Wildlife Refuge Complex, Charlestown, Rhode Island

Christopher Snow, Maryland Department of Natural Resources

Monica Williams, Long Island National Wildlife Refuge Complex, Shirley, New York

We wish to acknowledge the following organizations for their funding and logistical support:

Shimon Anisfeld thanks the US Environmental Protection Agency and Connecticut Sea Grant for funding to install and monitor surface elevation table (SET) stations.

Alice Benzecry gratefully acknowledges the support of Fairleigh Dickinson University and Meadowlands Environmental Research Institute (MERI) for funding to install and monitor SET stations. http:// meri.njmeadowlands.gov/projects/sea-level-rise-measurements/.

Linda Blum - SET and marker horizon (MH) data collection is based upon work supported by the NSF under Grant Nos. BSR-8702333-06, DEB-9211772, DEB-9411974, DEB-0080381, DEB-0621014, and DEB-1237733. The Virginia Coast Reserve of the Nature Conservancy provided access to study sites. Database citation for this data set is Blum et al. (2017)

J. Patrick Megonigal - SET data from the Smithsonian Environmental Research Center was funded by the Department of Energy Terrestrial Ecosystem Science Program (DE-FG0297ER62458), the US Geologic Survey (G10AC00675), the National Science Foundation Long-Term Research in Environmental Biology Program (DEB-0950080, DEB-1457100, DEB-1557009), Maryland Sea Grant (SA7528082, SA7528114WW), and the Smithsonian Institution.

Nicole Maher and Adam Starke with The Nature Conservancy in NY acknowledge the generous financial support for this work from the Zegar Family Foundation and the Pritchard Charitable Trust.

William Reay - Maintenance and monitoring of Chesapeake Bay National Estuarine Research Reserve (CBNERR) SET-MH stations is supported, in part, by NERR operational awards from the Office of Ocean and Coastal Management, NOAA.

Alice Yeates and Jennifer Olker acknowledge Center for Water and the Environment, Natural Resources Research Institute, University of Minnesota Duluth (contribution number: 639)

We wish to acknowledge the following people for assistance in field data collection and management, GIS, and in report preparation:

We thank Kristi Nixon, Natural Resources Research Institute, University of Minnesota Duluth, for GIS assistance. Glenn Guntenspergen thanks Patrick Brennand and Robert Derby for SET$\mathrm{MH}$ installation and monitoring. Ellen Kracauer Hartig thanks New York City Parks partners Rebecca Boger of Brooklyn College, City University of New York (CUNY), for providing funding for installing additional stations and Alice Benzecry of Fairleigh Dickinson University and her students who assisted with monitoring. Jenny Allen and Amanda Garzio-Hadzick assisted in the field at the Chesapeake Bay National Estuarine Research Reserve in Maryland. We thank Toni Mikula and Kate O'Brien at Rachel Carson National Wildlife Refuge (NWR), and Curtis George at Bombay Hook NWR for their support. Shimon Anisfeld thanks Troy Hill for assistance in monitoring SET-MH stations. Shannon Beliew, US Geological Survey, Patuxent Wildlife Research Center, updated the map figures for publication. William Reay thanks Jim Goins and Alex Demeo for assistance in SET-MH station installation and monitoring.

J Grace and Glenn Guntenspergen were supported by the USGS Land Change Science and Ecosystems Programs. Any use of trade, firm, or product names is for descriptive purposes only and does not imply endorsement by the US Government.

\section{References}

American Littoral Society. 2012. Assessing the impacts of Hurricane Sandy on coastal habitats: Final report to The National Fish and Wildlife Foundation, 2012, p. 58 www.nfwf.org/.../Documents/ Hurricane-Sandy-Coastal-Habitats.pdf. Accessed 23 January 2013.

Aretxabaleta, A., B. Butman, and N.K. Ganju. 2014. Water level response in back-barrier bays unchanged following Hurricane Sandy. Geophysical Research Letters 41: 3163-3171.

Aretxabaleta, A., N. K. Ganju, B. Butman, and Z. Defne. 2016. Backbarrier water level response to offshore fluctuations. American Geophysical Union, Ocean Sciences Meeting 2016

Bender, M.A., T.R. Knutson, R.E. Tuleya, J.J. Sirutis, G.A. Vecchi, S.T Garner, and I.M. Held. 2010. Modeled impact of anthropogenic warming on the frequency of intense Atlantic hurricanes. Science 327: 454-458.

Bivand, R., and G. Piras. 2015. Comparing implementations of estimation methods for spatial econometrics. Journal of Statistical Software 63 (18): 1-36 http://www.jstatsoft.org/v63/i18/. Accessed November 2016.

Bivand, R., E. Pebesma, and V.G. Bubio. 2013. Applied spatial data analysis with R. 2d ed, 405. New York: Springer Press.

Blake, E.S., T.B. Kimberlain, R.J. Berg, J.P. Cangialosi, and J.L. Beven II. 2013. Tropical cyclone report, Hurricane Sandy (AL182012) 2229 October 2012: National Oceanic and Atmospheric Administration, 157. Miami: National Hurricane Center.

Blum, L., R. Christian, M. Brinson, and P. Willis. 2017. Surface elevation data for the Upper Phillips Creek Marsh at the Virginia Coast Reserve, 1998-. Virginia Coast Reserve Long-Term Ecological Research Project Data Publication knb-lter-vcr.148.23. doi:https:// doi.org/10.6073/pasta/427e78ec51022e1ab667c6ce206b9025.

Booth, J. F., H. E. Rieder, and Y. Kushnir. 2016. Comparing hurricane and extratropical storm surge for the Mid-Atlantic and Northeast Coast of the United States for 1979-2013. Environmental Research Letters, v. 11, doi: https://doi.org/10.1088/1748-9326/11/9/094004

Bourke, P. 2015. http://paulbourke.net/geometry/pointlineplane/ pointline.r. Accessed September 2015.

Burnham, K.P., and D.R. Anderson. 2002. Model selection and multimodel inference - A practical information theoretic approach. $2 \mathrm{~d}$ ed, 488. New York: Springer.

Cahoon, D.R. 2006. A review of major storm impacts on coastal wetland elevations. Estuaries and Coasts 29 (6): 889-898.

Cahoon, D.R. 2015. Estimating relative sea-level rise and submergence potential at a coastal wetland. Estuaries and Coasts 38: 1077-1084.

Cahoon, D.R., and G.R. Guntenspergen. 2010. Climate change, sea-level rise, and coastal wetlands. National Wetlands Newsletter 32 (1): 8-12.

Cahoon, D.R., D.J. Reed, and J.W. Day. 1995. Estimating shallow subsidence in microtidal salt marshes of the southeastern United States-Kaye and Barghoorn revisited. Marine Geology 128 (12): $1-9$.

Cahoon, D.R., L.C. Lynch, P. Hensel, R. Boumans, B.C. Perez, B. Segura, and J.W. Day. 2002a. High-precision measurements of wetland sediment elevation-I. Recent improvements to the sedimentation-erosion table. Journal of Sedimentary Research 72 (5): 730-733.

Cahoon, D.R., J.C. Lynch, B.C. Perez, B. Segura, R.D. Holland, C. Stelly, G. Stephenson, and P. Hensel. 2002b. High-precision measurements of wetland sediment elevation-II. The rod surface elevation table. Journal of Sedimentary Research 72 (5): 734-739.

Cahoon, D.R., P. Hensel, J. Rybczyk, K.L. McKee, C.E. Proffitt, and B.C. Perez. 2003. Mass tree mortality leads to mangrove peat collapse at Bay Islands, Honduras after Hurricane Mitch. Journal of Ecology 91: 1093-1105. 
Cahoon, D. R., D. J. Reed, A. Kolker, M. M. Brinson, J. C. Stevenson, S. Riggs, R. Christian, E. Reyes, C. Voss, and D. Kunz. 2009. Coastal wetland sustainability. In Coastal sensitivity to sea-level rise-A focus on the mid-Atlantic region ed. J. G. Titus (coordinating lead author), K. E. Anderson, D. R. Cahoon, S. Gill, E. R. Thieler, and S. J. Williams (lead authors), 57-72. U.S. Environmental Protection Agency.

Callaway, J.C., D.R. Cahoon, and J.C. Lynch. 2013. The Surface Elevation Table-marker horizon method for measuring wetland accretion and elevation dynamics, in DeLaune, R.D., Reddy, K.R., Richardson, C.J., and Megonigal, J.P., editors, Methods in biogeochemistry of wetlands: Madison, Soil Science Society of America, SSSA Book Series 10, p. 901-918.

Castagno, K.A., A.M. Jiménez-Robles, J.P. Donnelly, P.L. Wiberg, M.S. Fenster, and S. Fagherazzi. 2018. Intense storms increase the stability of tidal bays. Geophysical Research Letters 45: 5491-5500. https://doi.org/10.1029/2018GL078208.

Core Team, R. 2016. $R-$ A language and environment for statistical computing. Vienna: R Foundation for Statistical Computing https://www.R-project.org/. Accessed August 2015.

Davis, R.E., and R. Dolan. 1993. Nor'easters. American Scientist 81: 428-439.

Day, J., R.R. Christian, D.M. Boesch, A. Yáñez-Arancibia, J. Morris, R.R. Twilley, L. Naylor, L. Schaffner, and C. Stevenson. 2008. Consequences of climate change on the ecogeomorphology of coastal wetlands. Estuaries and Coasts 31 (3): 477-491.

Day, J., G.P. Kemp, D. Reed, D. Cahoon, R. Boumans, J. Suhayda, and R. Gambrell. 2011. Vegetation death and rapid loss of surface elevation in two contrasting Mississippi delta salt marshes: The role of sedimentation, autocompaction and sea-level rise. Ecological Engineering 37: 229-240.

Dennison, W. C., T. Saxby, and B. M. Walsh, eds. 2012. Responding to major storm impacts - Chesapeake Bay and Delmarva Coastal Bays: Integration \& Application Network, University of Maryland Center for Environmental Science, 16 p. https://mdcoastalbays.org/ files/pdfs_pdf/HurricaneSandyAssessment-Final-1.pdf. Accessed 23 January 2013

Donatelli, C., N.K. Ganju, X. Zhang, S. Fagherazzi, and N. Leonardi. 2018. Salt marsh loss the sediment budget of shallow bays. Journal of Geophysical Research - Earth Surface. https://doi.org/ 10.1029/2018JF004617.

Dowle, M., A. Srinivasan, T. Short, and S. Lianoglou, with contributions from R. Saporta, and E. Antonyan. 2015. data.table-Extension of data.frame (v. 1.9.6): R package. https://CRAN.R-project.org/ package $=$ data.table. Accessed March 2017.

Emanuel, K.A. 2013. Downscaling CMIP5 climate models show increased tropical cyclone activity over the 21 st century. Proceedings of the National Academy of Sciences of the United States of America 110: 12219-12224.

Ezer, T., and L.P. Atkinson. 2014. Accelerated flooding along the U.S. east coast - On the impact of sea-level rise, tides, storms, the Gulf Stream, and the North Atlantic Oscillations. Earth's Future 2: 362 382.

Fagherazzi, S. 2014. Storm-proofing with marshes. Nature Geoscience 7: 701-702.

Federal Emergency Management Agency. 2015. FEMA Modeling Task Force (MOTF) Hurricane Sandy impact analysis: Federal Emergency Management Agency web page. http://www.arcgis. com/home/item.html?id=307dd522499d4a44a33d7296a5da5ea0. Accessed 29 February 2015.

Fox, J., and S. Weisberg. 2011. An R companion to applied regression. $2 \mathrm{~d}$ ed, 449. Thousand Oaks: Sage Publications.

Gardner, L.R., W.K. Michener, B. Kjerfve, and D.A. Karinshak. 1991. The geomorphic effects of Hurricane Hugo on an undeveloped coastal landscape at North Inlet, South Carolina. Journal of Coastal Research Special Issue 8: 181-186.
Gardner, L.R., W.K. Michener, T.M. Williams, E.R. Blood, B. Kjerfve, L.A. Smock, D.J. Lipscomb, and C. Gresham. 1992. Disturbance effects of Hurricane Hugo on a pristine coastal landscape-North Inlet, South Carolina, USA. Netherlands Journal of Sea Research 30: 249-263.

Grace, J.B. 2006. Structural equation modeling and natural systems. Cambridge: Cambridge University Press.

Grace, J.B., D.R. Schoolmaster Jr., G.R. Guntenspergen, A.M. Little, B.R. Mitchell, K.M. Miller, and E.W. Schweiger. 2012. Guidelines for a graph-theoretic implementation of structural equation modeling. Ecosphere 3 (8): 1-44. https://doi.org/10.1890/ES12-00048.1 .

Grubel, C., J. Waldman, J. Lodge, and D. Suszkowski. 2012. Rapid assessment of habitat and wildlife losses from Hurricane Sandy in the Hudson Raritan Estuary: Report by the Hudson River Foundation to The National Fish and Wildlife Foundation, December 12, 2012, 22 p. www.hudsonriver.org/download/HRF RAP Final Report - Sent 12-21-12.pdf. Accessed 23 January 2013.

Hall, T.M., and A.H. Sobel. 2013. On the impact angle of Hurricane Sandy's New Jersey landfall. Geophysical Research Letters 40: 2312-2315.

Hauser, S., M.S. Meixler, and M. Laba. 2015. Quantification of impacts and ecosystem services loss in New Jersey coastal wetlands due to Hurricane Sandy storm surge. Wetlands 35: 1137-1148.

Horton, R.M., V. Gornitz, D.A. Bader, A.C. Ruane, R. Goldberg, and C. Rosenzweig. 2011. Climate hazard assessment for stakeholder adaptation planning in New York City. Journal of Applied Meteorology and Climatology 50: 2247-2266.

Horton, R., G. Yohe, W. Easterling, R. Kates, M. Ruth, E. Sussman, A. Whelchel, D. Wolfe, and F. Lipschultz. 2014. Northeast. In Climate change impacts in the United States-The third national climate assessment, eds. J. M. Melillo, T. C. Richmond, and G. W. Yohe, 371-395. U.S. Global Change Research Program. http://nca2014. globalchange.gov.

Inamdar, S., S. Singh, S. Dutta, D. Levia, M. Mitchell, D. Scott, H. Bais, and P. McHale. 2011. Fluorescence characteristics and sources of dissolved organic matter for stream water during storm events in a forested mid-Atlantic watershed. Journal of Geophysical ResearchBiogeosciences 116 (G3). https://doi.org/10.1029/2011JG001735.

Kemp, A.C., and B.P. Horton. 2013. Contribution of relative sea-level rise to historical hurricane flooding in New York City. Journal of Quaternary Science 28 (6): 537-541.

Kemp, A.C., T.D. Hill, C.H. Vane, N. Cahil, P.M. Orton, S.A. Talke, A.C. Parnell, K. Sanborn, and E.K. Hartig. 2017. Relative sea-level trends in New York City during the past 1500 years. The Holocene 27 (8): 1169-1186. https://doi.org/10.1177/0959683616683263.

Knutson, T.R., J.L. McBride, J. Chan, K. Emanuel, G. Holland, C. Landsea, I. Held, J.P. Kossin, A.K. Srivastava, and M. Sugi. 2010. Tropical cyclones and climate change. Nature Geoscience 3: 157163.

Leonardi, N., I. Carnacina, C. Donatelli, N. Ganju, A. Plater, M. Schuerch, and S. Temmerman. 2018. Dynamic interactions between coastal storms and salt marshes-A review. Geomorphology 301: 92-107.

Lin, N., R.E. Kopp, B.P. Horton, and J.P. Donnelly. 2016. Hurricane Sandy's flood frequency increasing from year 1800 to 2100 . Proceedings of the National Academy of Sciences 113 (43): 12071-12075.

Little, C.M., R.M. Horton, R.E. Kopp, M. Oppenheimer, G.A. Vecchi, and G. Villarini. 2015. Joint projections of US East coast sea level and storm surge. Nature Climate Change 5: 1114-1120.

Longenecker, R., J. Bowman, B. Olsen, S. Roberts, C. Elphick, P. Castelli, and W.G. Shriver. 2018. Short-term resilience of New Jersey tidal marshes to Hurricane Sandy. Wetlands 38 (3): 565 575. https://doi.org/10.1007/s13157-018-1000-2.

Lynch, J.C., P. Hensel, and D.R. Cahoon. 2015. The surface elevation table and marker horizon technique: A protocol for monitoring 
wetland elevation dynamics. In Natural Resource Report NPS/ $N C B N / N R R$-2015/1078. Fort Collins: National Park Service.

Mallin, M., and C. Corbett. 2006. How hurricane attributes determine the extent of environmental effects: Multiple hurricanes and different coastal systems. Estuaries and Coasts 29 (6): 1046-1061.

Marsh, A., L.K. Blum, R.R. Christian, E. Ramsey III, and A. Rangoonwala. 2016. Response and resilience of Spartina alterniflora to sudden dieback. Journal of Coastal Conservation 20 (4): 335 350

Mazerolle, M. J. 2016. AICcmodavg-Model selection and multi-model inference based on (Q)AIC(c) (v. 2.0-4). R package. http://CRAN. R-project.org/package=AICcmodavg. Accessed August 2016.

Middleton, B. 2016. Differences in impacts of Hurricane Sandy on freshwater swamps on the Delmarva Peninsula, Mid-Atlantic Coast, USA. Ecological Engineering 87: 62-70.

Moher, D., A. Liberati, J. Tetzlaff, and D.G. Altman. 2009. Preferred reporting items for systematic reviews and meta-analyses-The PRISMA statement. PLoS Medicine 6 (6): e1000097. https://doi. org/10.1371/journal.pmed1000097.

Moller, I., M. Kudella, F. Rupprecht, T. Spencer, M. Paul, B.K. van Wesenbeeck, G. Wolters, K. Jensen, T.J. Bouma, M. MirandaLange, and S. Schimmels. 2014. Wave attenuation over coastal salt marshes under storm surge conditions. Nature Geoscience 7: 727731.

Narayan, S., M. Beck, P. Wilson, C. Thomas, A. Guerrero, C. Shepard, B. Reguero, G. Franco, J. Ingram, and D. Trespalacios. 2017. The value of coastal wetlands for flood damage reduction in the northeastern USA. Nature Scientific Reports. https://doi.org/10.1038/s41598017-09269-Z

National Aeronautics and Space Administration. 2013. Hurricane Sandy (Atlantic Ocean), October 28, 2013. National Aeronautics and Space Administration web page www.nasa.gov/mission_pages/ hurricanes/archives/2012/h2012 Sandy.html. Accessed 3 March 2017.

National Oceanic and Atmospheric Administration. 2010. County by county hurricane strikes (1900-2009). National Oceanic and Atmospheric Administration, National Hurricane Center web page, last updated February 2010. www.nhc.noaa.gov/ms-excel/ HurricaneStrikes 20100204.xls. Accessed 29 July 2015.

National Oceanic and Atmospheric Administration 2014. NOAA/National Hurricane Center preliminary best track tropical cyclone tracks [file: al182012 best track.zip]. National Oceanic and Atmospheric Administration, National Hurricane Center. http://www.nhc.noaa.gov/gis/. Accessed 29 July 2015.

Pebesma, E. J., and R. S. Bivand. 2005. Classes and methods for spatial data in R. R News 5(2) http://cran.r-project.org/doc/Rnews/. Accessed April 2015.

Peduzzi, P., B. Chatenoux, H. Dao, A. De Bono, C. Herold, J. Kossin, F. Mouton, and O. Nordbeck. 2012. Global trends in tropical cyclone risk. Nature Climate Change 2: 289-294.

Prandle, D., and J. Wolf. 1978. The interaction of surge and tide in the North Sea and River Thames. Geophysical Joural International 55 (1): 203-216

Quirk, T. 2016. Impact of Hurricane Sandy on salt marshes of New Jersey. Estuarine. Coastal and Shelf Science 183: 235-248.

Rachlin, J.W., R. Stalter, D. Kincaid, and B.E. Warkentine. 2017. The effect of Superstorm Sandy on salt marsh vascular flora in the New York Bight. Journal of the Torrey Botanical Society 144 (1): 40-46.

Rangoonwala, A., N. Enwright, E. Ramsey, and J. Spruce. 2016. Radar and optical mapping of surge persistence and marsh dieback along the New Jersey Mid-Atlantic coast after Hurricane Sandy. International Journal of Remote Sensing 37: 1692-1713.
Reed, D.J. 2002. Sea-level rise and coastal marsh sustainabilityGeological and ecological factors in the Mississippi delta plain. Geomorphology 48: 233-243.

Reed, A.J., M.E. Mann, K.A. Emanuel, N. Lin, B.P. Horton, A.C. Kemp, and J.P. Donnelly. 2015. Increased threat of tropical cyclones and coastal flooding to New York City during the anthropogenic era. Proceedings of the National Academy of Sciences 112 (41): 12610-12615.

Resio, D.T., and J.J. Westerink. 2008. Modeling the physics of storm surges. Physics Today 61: 33-38.

Rupprecht, F., I. Moller, M. Paul, M. Kudella, T. Spencer, B.K. van Wesenbeeck, G. Wolters, K. Jensen, T.J. Bouma, M. MirandaLange, and S. Schimmels. 2017. Vegetation-wave interactions in salt marshes under storm surge conditions. Ecological Engineering 100: 301-315.

Sallenger, A.H., K.S. Doran, and P.A. Howd. 2012. Hotspot of accelerated sea-level rise on the Atlantic coast of North America. Nature Climate Change 2: 884-888.

Sopkin, K. L., H. F. Stockdon, K. S. Doran, N. G. Plant, K. L. M. Morgan, K. K. Guy, and K. E. L. Smith. 2014. Hurricane SandyObservations and analysis of coastal change. U.S. Geological Survey Open-File Report 2014-1088, 54 p. 10.3133/ofr20141088. Accessed July 2015

Stevenson, J.C., L.G. Ward, and M.S. Kearney. 1988. Sediment transport and trapping in marsh system-Implications of tidal flux studies. Marine Geology 80: 37-59.

Sweet, W. V., R. E. Kopp, C. P. Weaver, J. Obeysekera, R. M. Horton, E. R. Thieler, and C. Zervas, 2017. Global and regional sea level rise scenarios for the United States. National Oceanic and Atmospheric Administration Technical Report NOS CO-OPS 083, 55 p. + appendices.

Talke, S.A., P. Orton, and D.A. Jay. 2014. Increasing storm tides in New York Harbor, 1844-2013. Geophysical Research Letters 41: 31493155.

Tebaldi, C., B.H. Strauss, and C.E. Zervas. 2012. Modelling sea level rise impacts on storm surges along US coasts. Environmental Research Letters 7 (1). https://doi.org/10.1088/1748-9326/7/1/014032.

Temmerman, S., P. Meire, T.J. Bouma, P.M.J. Herman, T. Ysebaert, and H.J. De Vriend. 2013. Ecosystem-based coastal defence in the face of global change. Nature 504: 79-83.

Valle-Levinson, A., M. Olabarrieta, and A. Valle. 2013. Semi-diurnal perturbations to the surge of Hurricane Sandy. Geophysical Research Letters 40: 2211-2217.

Wang, H., Q. Chen, K. Hu, G. A. Snedden, E. K. Hartig, B. R. Couvillion, C. L. Johnson, and P. M. Orton. 2017. Numerical modeling of the effects of Hurricane Sandy and potential future hurricanes on spatial patterns of salt marsh morphology in Jamaica Bay, New York City. U.S. Geological Survey Open-File Report 2017-1016, 43 p. 10.3133/ofr20171016. Accessed March 2018.

Webb, E.L., D.A. Friess, K.W. Krauss, D.R. Cahoon, G.R. Guntenspergen, and J. Phelps. 2013. A global standard for monitoring coastal wetland vulnerability to accelerated sea-level rise. Nature Climate Change 3: 458-465.

Wickham, H. 2007. Reshaping data with the reshape package. Journal of Statistical Software 21(12). http://www.jstatsoft.org/v21/i12/. Accessed March 2017.

Wickham, H. 2014. Tidy data. Journal of Statistical Software 59(10). http://www.jstatsoft.org/V59/i10/. Accessed March 2017.

Woodruff, J.D., J.L. Irish, and S.J. Camargo. 2013. Coastal flooding by tropical cyclones and sea-level rise. Nature 504: 44-52.

Zuur, A.F., E.N. Ieno, N.J. Walker, A.A. Saveliev, and G.M. Smith. 2009. Mixed effects models and extensions in ecology with $R, 574 \mathrm{p}$. New York: Springer. 


\section{Affiliations}

Alice G. Yeates ${ }^{1}$ - James B. Grace ${ }^{2}$ • Jennifer H. Olker ${ }^{1}$ - Glenn R. Guntenspergen ${ }^{3}$ - Donald R. Cahoon ${ }^{3}$ (D) Susan Adamowicz ${ }^{4}$. Shimon C. Anisfeld ${ }^{5}$. Nels Barrett ${ }^{6}$ - Alice Benzecry ${ }^{7} \cdot$ Linda Blum $^{8} \cdot$ Robert R. Christian $^{9}$. Joseph Grzyb ${ }^{10}$. Ellen Kracauer Hartig ${ }^{11,12}$. Kelly Hines Leo ${ }^{13}$. Scott Lerberg ${ }^{14}$ • James C. Lynch ${ }^{15}$. Nicole Maher ${ }^{16}$. J. Patrick Megonigal ${ }^{17} \cdot$ William Reay $^{14} \cdot$ Drexel Siok $^{18} \cdot$ Adam Starke $^{13} \cdot$ Vincent Turner $^{19} \cdot$ Scott Warren ${ }^{20}$

1 University of Minnesota - Duluth, Duluth, USA

2 U.S. Geological Survey, Wetland and Aquatic Research Center, Lafayette, USA

3 U.S. Geological Survey, Patuxent Wildlife Research Center, Laurel, USA

4 U.S. Fish and Wildlife Service, Rachel Carson National Wildlife Refuge, Wells, USA

5 School of Forestry and Environmental Studies, Yale University, New Haven, USA

6 Natural Resources Conservation Service, Washington, DC, USA

7 Fairleigh Dickinson University, Teaneck, USA

8 Virginia Coast Reserve LTER, University of Virginia, Charlottesville, USA

9 Virginia Coast Reserve LTER, East Carolina University, Greenville, USA

10
11 New York City Parks, New York City, USA

12 The Graduate Center, City University of New York, New York City, USA

13 The Nature Conservancy, Maryland, DC, Bethesda, USA

14 Chesapeake Bay National Estuarine Research Reserve, Virginia Institute of Marine Science, Gloucester Point, USA

15 National Park Service, Northeast Coastal \& Barrier Network, Washington, DC, USA

16 The Nature Conservancy, Long Island, NY, USA

17 Smithsonian Environmental Research Center, Edgewater, USA

18 Delaware Department of Natural Resources and Environmental Control, Delaware National Estuarine Research Reserve, Delaware, USA

19 U.S. Fish and Wildlife Service, Edwin B. Forsythe National Wildlife Refuge, Galloway, USA

20 Connecticut College, New London, USA 